\title{
Composition, Clay Mineralogy, and Diagenesis of the Simpson Group (Middle Ordovician), Grady County, Oklahoma
}

\section{U.S. GEOLOGICAL SURVEY BULLETIN 1866-H}

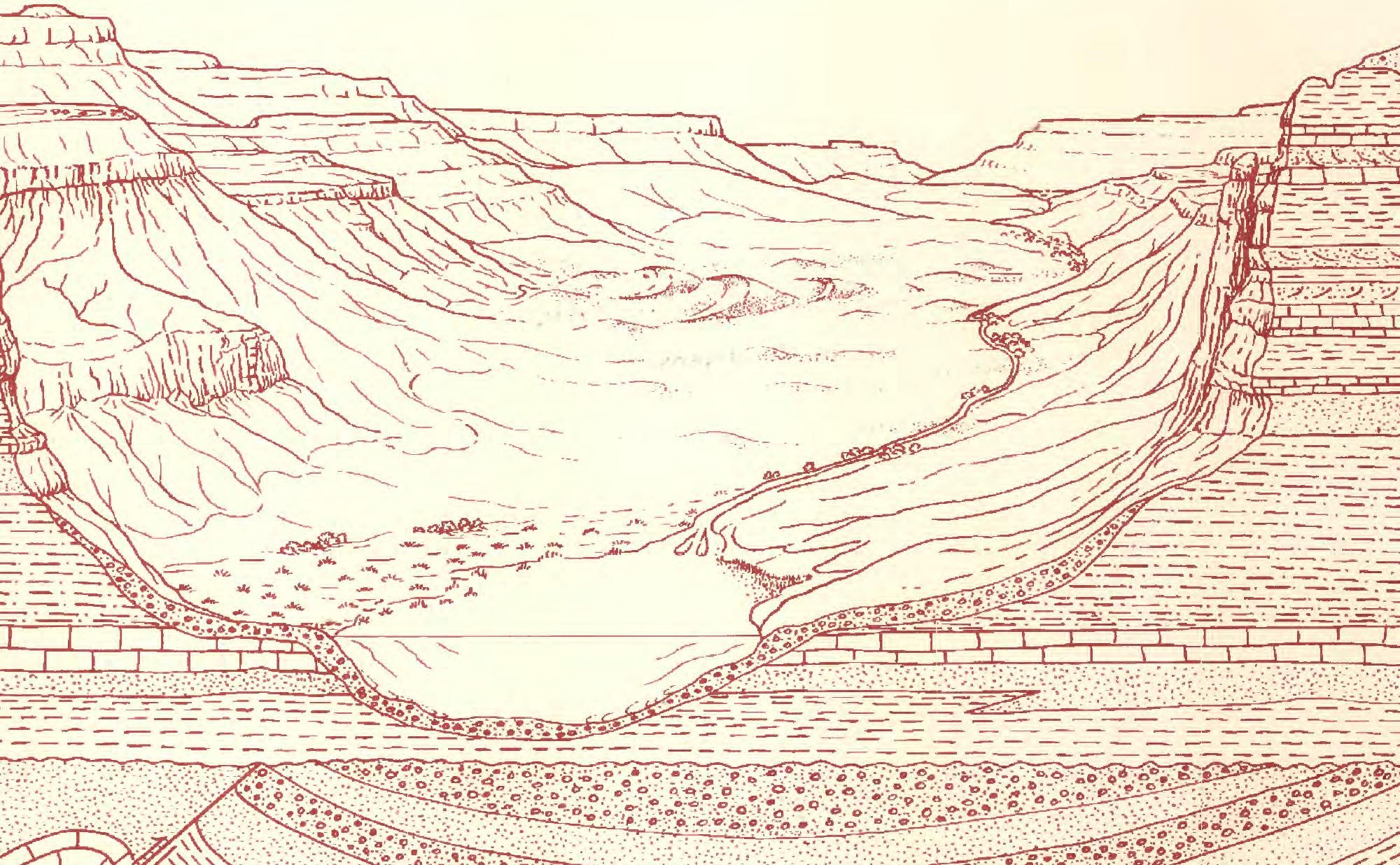




\section{AVAILABILITY OF BOOKS AND MAPS OF THE U.S. GEOLOGICAL SURVEY}

Instructions on ordering publications of the U.S. Geological Survey. along with the last offerings. are given in the current-year issues of the monthly catalog "New Publications of the U.S. Geological Survey." Prices of available U.S. Geological Survey publications released prior to the current year are listed in the most recent annual "Price and Availability List." Publications that are listed in various U.S. Geological Survey catalogs (see back inside cover) but not listed in the most recent annual "Price and Availability List" are no longer available.

Prices of reports released to the open files are given in the listing "U.S. Geological Survey Open-File Reports." updated monthly, which is for sale in microfiche from the U.S. Geological Survey, Books and Open-File Reports Section. Federal Center. Box 25425, Denver. CO 80225. Reports released through the NTIS may be obtained by writing to the National Technical Information Service, U.S. Department of Commerce. Springfield, VA 22161; please include NTIS report number with inquiry.

Order U.S. Geological Survey publications by mail or over the counter from the offices given below.

\section{BY MAIL}

\section{Books}

Professional Papers, Bulletins, Water-Supply Papers, Techniques of Water-Resources Investigations, Circulars, publications of general interest (such as leaflets, pamphlets, booklets), single copies of periodicals (Earthquakes \& Volcanoes. Preliminary Determination of Epicenters), and some miscellaneous reports, including some of the foregoing series that have gone out of print at the Superintendent of Documents, are obtainable by mail from

\section{U.S. Geological Survey, Books and Open-File Reports Section Federal Center, Box 25425 Denver, CO 80225}

Subscriptions to periodicals (Earthquakes \& Volcanoes and Preliminary Determination of Epicenters) can be obtained ONLY from

\section{Superintendent of Documents \\ U.S. Government Printing Office Washington, DC 20402}

(Check or money order must be payable to Superintendent of Documents.)

Maps

For maps, address mail orders to

\section{U.S. Geological Survey, Map Distribution Federal Center, Box 25286 Denver, CO 80225}

Residents of Alaska may order maps from

\author{
U.S. Geological Survey, Map Distribution \\ New Federal Building - Box 12 \\ 101 Twelfth Ave., Fairbanks, AK 99701
}

\section{OVER THE COUNTER}

\section{Books}

Books of the U.S. Geological Survey are available over the counter at the following U.S. Geological Survey offices, all of which are authorized agents of the Superintendent of Documents:

- ANCHORAGE, Alaska-4230 University Dr., Rm. 10]

- ANCHORAGE, Alaska-605 West th Ave. Rm. G-84

- DENVER, Colorado-Federal Bldg., Rm. 169, 1961 Stout St.

- LOS ANGELES, California-Federal Bldg., Rm. 7638. 300 North Los Angeles St.

- MENLO PARK, California-Bldg, 3, Rm. 3128, 345 Middlefield Rd.

- RESTON, Virginia-National Center, Rm. IC402, 1220] Sunrise Valley Dr.

- SALT LAKE CITY, Utah-Federal BIdg., Rm. 8105. 125 South State St.

- SAN FRANCISCO, California-Customhouse, Rm. $5(1) 4$. 555 Battery St.

- SPOKANE, Washington-U.S. Courthouse, Rm. 678. West 920 Riverside Ave.

- WASHINGTON, DC-U.S. Department of the Interior Bldg., Rm. 2650, 1849 C St., NW.

Maps

Maps may be purchased over the counter at the U.S. Geological Survey offices where books are sold (all addresses in above list) and at the following U.S. Geological Survey offices:

- ROLLA, Missouri-1400 Independence Rd.

- FAIRBANKS, Alaska-New Federal Bldg.. 101 Twelfth Ave. 
Chapter H

\title{
Composition, Clay Mineralogy, and Diagenesis of the Simpson Group (Middle Ordovician), Grady County, Oklahoma
}

\author{
By RICHARD M. POLLASTRO
}

A multidisciplinary approach to research studies of sedimentary rocks and their constituents and the evolution of sedimentary basins, both ancient and modern 


\title{
U.S. DEPARTMENT OF THE INTERIOR MANUEL LUJAN, JR., Secretary
}

\author{
U.S. GEOLOGICAL SURVEY
}

Dallas L. Peck, Director

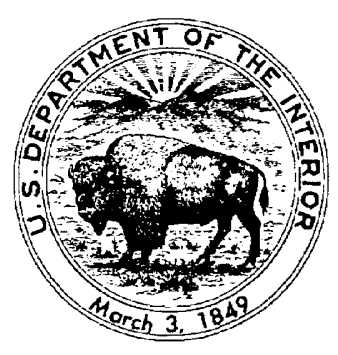

Any use of trade, product, or firm names in this publication is for descriptive purposes only and does not imply endorsement by the U.S. Government.

For sale by the

Books and Open-File Reports Section

U.S. Geological Survey

Federal Center

Box 25425

Denver, CO 80225

\section{Library of Congress Cataloging-in-Publication Data}

Pollastro, Richard $M$.

Composition, clay mineralogy, and diagenesis of the Simpson Group (Mlddle Ordovician), Grady County, Oklahoma / by Richard M. Pollastro.

p. $\mathrm{cm}$.--(Evolution of sedimentary basins-Anadarko basin ; ch. H)

(U.S. Geological Survey bulletin ; 1866H)

Includes bibliographical references. (p. ).

Supt. of Docs. no.: ! 19.3:1866H

1. Sandstone-Anadarko Basin. 2. Geology, Stratigraphic-Ordovician.

3. Geology-Anadarko Basin. 4. Geology-Oklahoma-Grady County.

I. Title. II. Series. III. Series: U.S. Geological Survey bulletin ; $1866 \mathrm{H}$.

QE75.B9 no. $1866-\mathrm{H}$

[QE471.15.S25]

$557.3 \mathrm{~s}-\mathrm{dc} 20$

[552'.5] 


\title{
CONTENTS
}

\author{
Abstract H1 \\ Introduction H1 \\ Geologic setting and stratigraphy $\mathbf{H 2}$ \\ Methodology $\mathbf{H 3}$ \\ Results and discussion $\quad \mathbf{H 3}$ \\ Whole-rock mineralogy \\ Sandstone petrology $\quad \mathbf{H} 7$ \\ Composition and porosity $\quad \mathbf{H} 7$ \\ Diagenesis $\quad$ H8 \\ Clay mineralogy H9 \\ Clay diagenesis $\mathbf{H 1 1}$ \\ Formation of dolomite and ankerite cements $\quad \mathbf{H 1 5}$ \\ Summary H15 \\ References cited H16
}

\section{FIGURES}

1. Map showing sedimentary rock thickness in greater Anadarko basin and location of Sunray DX, Parker No. 1, Mazur well, Grady County, Oklahoma $\mathbf{H 2}$

2. Chart showing stratigraphy of rocks of the Simpson Group and cored intervals studied in the Mazur well $\mathbf{H 3}$

3. Ternary diagram showing mineral composition and lithology for samples of the Simpson Group from the Mazur well $\mathbf{H 4}$

4. Partial ternary diagram showing composition of sandstones of the Simpson Group from the Mazur well determined using point-count analysis H8

5-6. Thin section photomicrographs of rocks of the Simpson Group from the Mazur well:

5. Sandstones from the Tulip Creek and Oil Creek Formations $\mathbf{H 1 0}$

6. Quartzarenites from the Tulip Creek and Bromide Formations $\mathbf{H 1 1}$

7. Diagram showing paragenetic sequence for sandstones of the Simpson Group in the Mazur well $\mathbf{H 1 2}$

8. Scanning electron micrographs of sandstones of the Simpson Group from the Mazur well $\mathbf{H 1 2}$

9. Thin section photomicrographs of sandstones of the Simpson Group from the Mazur well H13

10. Scanning electron micrographs of sandstones of the Simpson Group from the Mazur well H13

11. Thin section photomicrographs of sandstones of the Simpson Group from the Mazur well H14

12. Typical X-ray powder diffraction profiles of rocks of the Simpson Group from the Mazur well $\mathbf{H 1 5}$

13. Scanning electron micrographs showing morphology of rocks of the Simpson Group from the Mazur well $\mathbf{H 1 6}$

14. Diagramatic interpretation and thin section photomicrograph showing formation of authigenic dolomite and ankerite in deeply buried rocks of the Simpson Group from the Mazur well 


\section{TABLES}

1. Mineralogical data from X-ray powder diffraction for samples from the Mazur well $\mathbf{H 5}$

2. Range and mean whole-rock mineralogic composition for 36 samples of shale and 50 samples of sandstone from the Mazur well

H7

3. Comparison of average mineralogic composition of Simpson Group shale from the Mazur well and typical shale and bentonite

H8

4. Point-count compositional analysis of 32 thin sections of sandstone from the Mazur well $\mathbf{H 9}$

5. Average clay-mineral composition and range for 62 samples of shale and carbonate rocks and 50 samples of sandstone from the Simpson Group in the Mazur well $\mathbf{H 1 0}$ 


\title{
Composition, Clay Mineralogy, and Diagenesis of the Simpson Group (Middle Ordovician), Grady County, Oklahoma
}

\author{
By Richard M. Pollastro
}

\begin{abstract}
Mineralogic and petrologic analyses were performed on more than 110 core samples of the Middle Ordovician Simpson Group in the Sunray DX, Parker No. 1, Mazur well, Grady County, Oklahoma. Core was recovered from present depths in the Anadarko basin of about 15,900-17,200 ft and includes (in descending order) all or parts of the Bromide, Tulip Creek, McLish, Oil Creek, and Joins Formations of the Simpson Group.

The whole-rock mineral composition of the samples is mainly related to varying lithology and degree of carbonate cementation. Most shale is clay rich and quartz poor, averaging about 85 percent clay minerals, 7 percent quartz, and 3 percent feldspar, by weight, as determined using X-ray powder diffraction. The high clay/quartz ratios suggest that much of the shale may have formed from either reworked, altered volcanic ash or that silica was expelled from shale by diagenetic processes during burial. Most sandstone is quartzarenite and some subfeldspathic arenite; quartz graywacke is also present. Little late silica cement is found in adjacent sandstones; however, early quartz overgrowth cement is ubiquitous in most sandstones. Excess silica from the alteration of glass to clay or expelled from shale during diagenesis and then transported updip in solution may have been a source for early silica cement in shallower sandstones.

Discrete illite and interstratified illite/smectite having low $(<15$ percent) expandability $(R \geq 1)$ are the main clay minerals. Iron-rich, authigenic chlorite cement is locally concentrated in some sandstones. Illite and illite/smectite commonly make up more than 90 relative weight percent of the clay minerals in sandstone and more than 95 relative weight percent of those in shale and carbonate rocks.
\end{abstract}

Manuscript approved for publication November 5, 1990.
Scanning electron microscopy reveals that much of the illite is diagenetic and is present as tabular fibers in pores or as pseudomorphic intergrowths after smectite. Illite is also present as overgrowths evident as sericitic cement in thin section examination. Most chlorite in sandstones is authigenic and is present as pore-lining cement or as pseudomorphic replacement after kaolinite. A clay-mineral assemblage consisting of illite, ordered illite/smectite $(R \geq 1)$, and chlorite and without smectite and kaolinite suggests that burial temperatures exceeded $150{ }^{\circ} \mathrm{C}$. This interpretation is supported by burial- and thermal-history reconstructions for the Mazur well.

Carbonate cements are abundant throughout the entire Simpson sequence. Early iron-poor calcite cement is commonly replaced by iron-rich calcite, dolomite, or ankerite. Rhombic dolomite in sandstone and in carbonate rocks commonly has overgrowths of ferroan dolomite or ankerite. Cementation and (or) replacement by ankerite is later than calcite or iron-free dolomite and is generally less selective. Dolomite and ankerite cements commonly replace detrital clay and calcite. Spatial and textural relations suggest that the conversion of smectite to illite contributed, in part, to the formation of dolomite and ankerite cements.

Secondary porosity, formed mainly from the dissolution of intergranular carbonate cements, is best developed in sandstones from the Oil Creek and Tulip Creek Formations. Maximum porosity measured from point-count analysis is 11 percent.

\section{INTRODUCTION}

An understanding of diagenesis is critical to any study in sedimentary basin analysis or petroleum geology. In particular, studies that relate effects of diagenesis to the quality of petroleum reservoir rocks and the maturity of potential source rocks are most critical (Scholle and Schluger, 1979; McDonald and Surdam, 1984; Gautier, 
1986; Naeser and McCulloh, 1989; Surdam and others, 1989).

Although commonly incomplete, a physical and chemical record of depositional and diagenetic conditions can be interpreted from mineralogic and petrologic studies of buried sedimentary rocks. The initial mineralogy and petrology of a potential reservoir rock have a strong influence on its reaction to postdepositional conditions. Therefore, a good understanding of the original detrital components allows a much better perspective for studying diagenesis. Numerous case history studies illustrate that potential reservoir rocks that have been deeply buried commonly have undergone several cementation and dissolution events. For example, petrographic data reported here and in Weber (1987) and Pitman and Burruss (1989) classify a large number of sandstones from the Simpson Group in the Mazur well as quartzarenite having a detrital framework composition of more than 95 volume percent quartz. Bulk compositions of these same sandstones, however, show that they contain as much as 45 volume percent authigenic constituents. Other studies refer to some of the sandstones as diagenetic quartzarenites in which detrital compositions have been modified extensively by diagenesis (McBride, 1987).

Clay minerals can also provide information on the geologic framework and diagenetic history of sedimentary rocks and basins. They are used as compositional, directional, and distance indicators relative to source terrains (Carson and Arcaro, 1983) and as environmental indicators of conditions during deposition and subsequent burial (Weaver, 1979; Hower, 1981). In some cases, systematic changes in clay minerals with progressive burial depth in a sedimentary basin can be used to predict the thermal history of the basin and, in many cases, provide information on the thermal maturity of source beds (Hoffman and Hower, 1979; Weaver, 1979; Burtner and Warner, 1986; Pollastro and Barker, 1986; Pollastro and Scholle, 1986; Schoonmaker and others, 1986; Scotchman, 1987; Pollastro and Schmoker, 1989).

This report describes the mineralogic and petrologic composition and diagenesis of deeply buried rocks of the Simpson Group sampled from core in the Anadarko basin, Oklahoma. It presents data and interpretations to supplement those reported previously by Pollastro (1989a). Although samples of all rock types within the Simpson Group were analyzed for mineral composition, this report focuses on the petrography and diagenesis of sandstone and shale, in particular the nature, occurrence, and origin of clay minerals in these rocks.

Acknowledgments.-I would like to thank Chris Schenk and Paula Hansley for their critical reviews and Judy Stoeser for editing of the manuscript. Their comments and suggestions greatly improved the final publication.

\section{GEOLOGIC SETTING AND STRATIGRAPHY}

The Anadarko basin of western Oklahoma, southwestern Kansas, and the northern part of the Texas Panhandle is one of the deepest Paleozoic basins in North America (fig. 1). In its deepest part sedimentary rocks are about $40,000 \mathrm{ft}$ thick. The Anadarko basin contains numerous hydrocarbon-bearing intervals in both clastic and carbonate rocks. Thick, organic-rich shales of Devonian to Early Mississippian and Pennsylvanian age are the primary hydrocarbon source rocks for these reservoirs (Alder, 1971).

The Anadarko basin is markedly asymmetrical; its steep limb and axis are adjacent to, and parallel with, the northwest-trending Amarillo-Wichita uplift that borders the basin to the south; relatively stable shelf areas are to the north. The principal tectonic elements of the basin were formed during the Wichita orogeny from the late Morrowan through early Desmoinesian (Rascoe and Adler, 1983). As a result of concurrent growth and erosion of the AmarilloWichita Mountains from the Early Pennsylvanian to the Early Permian, pre-Pennsylvanian rocks were eroded and the sediments deposited in the basin as a terrigenous clastic wedge. The Arbuckle Mountains to the southeast were not formed until the Late Pennsylvanian. The thermal history of the Anadarko basin has been described in detail by Schmoker (1986).

The Simpson Group consists of five formations, as first proposed by Decker and Merritt (1931), and includes all rocks from the top of the Arbuckle Group to the base of the Viola Limestone (fig. 2). The five formations, in ascending stratigraphic order, are the Joins, Oil Creek, McLish, Tulip Creek, and Bromide. The Simpson Group is made up of sandstones, shales, and carbonate rocks, most of which were deposited in relatively shallow marine

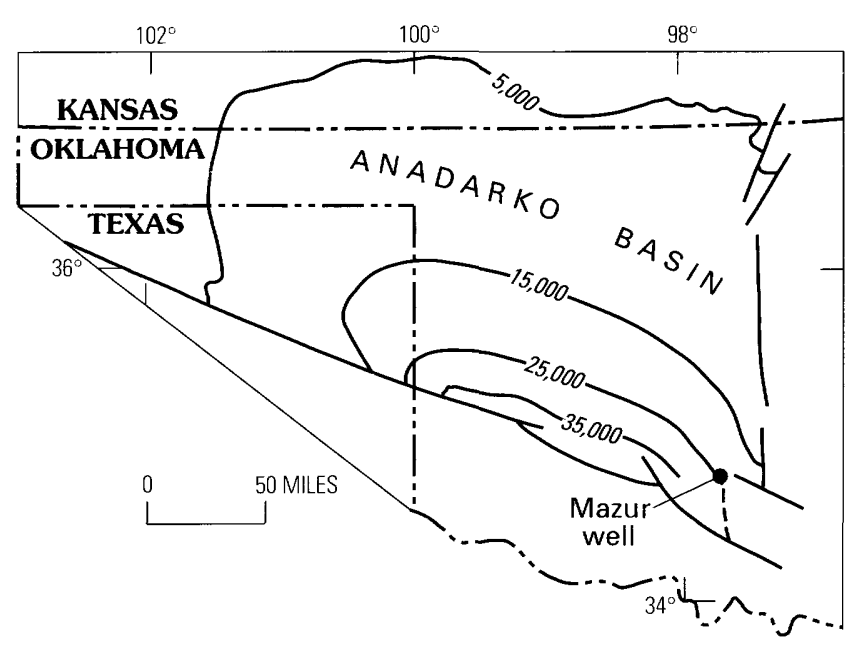

Figure 1. Sedimentary rock thickness in the greater Anadarko basin and location of Sunray DX, Parker No. 1, Mazur well, Grady County, Oklahoma (sec. 1, T. 3 N., R. 5 W.). Thickness contours are in feet. Heavy solid lines are faults. 


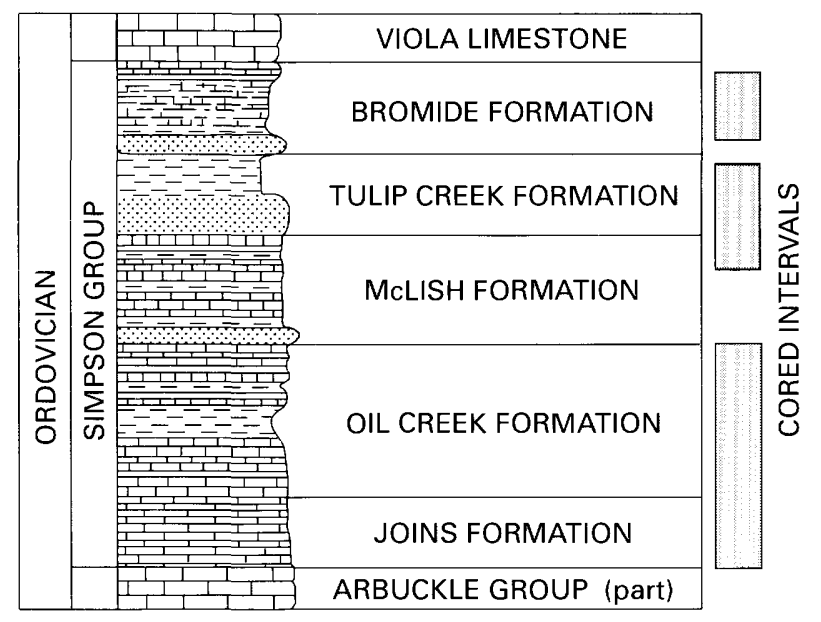

Figure 2. Stratigraphy of rocks of the Simpson Group and cored intervals studied in the Mazur well. Modified from Johnson and others (1984).

environments (Longman, 1976; Lewis, 1982). Regional paleogeography and detailed lithofacies maps of the Simpson Group have been published by Schramm (1964).

\section{METHODOLOGY}

Approximately 110 samples of sandstone, shale, and carbonate were obtained from core of the Sunray DX, Parker No. 1, Mazur well, Grady County, Oklahoma (sec. 1, T. 3 N., R. 5 W.) (fig. 1). The cored intervals were recovered between present depths of about 15,900 and $17,200 \mathrm{ft}$ and include parts or all of each of the five formations of the Simpson Group (fig. 2).

Plugs, 1 in. in diameter, were taken from all rock types represented in the core. Half of each plug was prepared for X-ray powder diffraction (XRD) analysis; the other half was used for thin section analysis and scanning electron microscopy (SEM).

Samples for XRD were washed and scrubbed to remove surficial contaminants, dried, and then ground to $<35$ mesh. Each sample was then split using a Jones splitter into two portions for (1) whole-rock XRD and (2) carbonate dissolution and clay-mineral analysis. Carbonate was dissolved in $1 \mathrm{~N} \mathrm{HCl}$ and the residue filtered and washed immediately after effervescence stopped so as to minimize solution of noncarbonate minerals (Pollastro, 1977). The insoluble residue was dried overnight at $65^{\circ} \mathrm{C}$. The weight percent of the residue and (or) carbonate was then determined. A small part of the residue was spot-checked for undissolved carbonate using $6 \mathrm{~N} \mathrm{HCl}$. For this study, carbonate rocks are defined as those containing 50 percent, by weight, or more carbonate minerals. Similarly, quartz sandstones are defined by XRD analysis as those containing 50 percent or more quartz, and shale as those containing 50 percent or more clay minerals.
Qualitative and semiquantitative estimates of the minerals in whole-rock samples were made using XRD analysis of randomly oriented powders that were ground to a maximum grain size of $44 \mu \mathrm{m}(<325$ mesh) and packed from the back side into aluminum specimen holders. A fine random texture was imparted onto the surface to be irradiated in order to further disrupt any preferred orientation created while mounting the sample (see Schultz, 1978). Semiquantitative weight percent values for total clay (phyllosilicates) and other minerals or mineral groups were calculated by comparison with several prepared mixtures of minerals having similar XRD characteristics using the procedures outlined by Schultz (1964) and Hoffman (1976) and modified by Pollastro (1985). The semiquantitative relative weight percent values calculated for total carbonate minerals by XRD were then compared with those determined using chemical dissolution.

Oriented clay aggregates of the $<2-\mu \mathrm{m}$ and $<0.25-\mu \mathrm{m}$ (equivalent spherical diameter) fractions were prepared using a modified filter-membrane-peel technique (Pollastro, 1982) similar to that described by Drever (1973). Semiquantitative XRD analysis of the clay-sized fractions were made using the method of Schultz (1964) as modified by Pollastro (1985). Composition and ordering of interstratified illite/ smectite (I/S) clay was determined on oriented, ethylene glycol-saturated specimens of both the $<2-\mu \mathrm{m}$ and $<0.25$ $\mu \mathrm{m}$ fractions using the methods of Reynolds and Hower (1970) and Reynolds (1980).

Thin sections were impregnated with blue epoxy to aid in recognizing porosity. Each section was then stained with potassium ferrocyanide and alizarin red for identification of carbonate phases (Dickson, 1966) and with potassium cobaltnitrite to distinguish potassium feldspar from plagioclase. Sandstone compositions were determined for thin sections based on a minimum of 300 counts and using the classification scheme of Pettijohn and others (1973) with some modification.

SEM and energy-dispersive chemical analyses were performed on samples of freshly fractured rock chips. Each sample was mounted on aluminum stubs, air dusted, and coated with about 100 angstroms of a gold-palladium mixture.

\section{RESULTS AND DISCUSSION}

\section{Whole-Rock Mineralogy}

The whole-rock compositions, as determined using $\mathrm{XRD}$, for all samples are given in table 1. For simplification, the data are summarized in the ternary diagram of figure 3. The three end members of figure 3-quartz, total clay, and total carbonate-represent the three major mineral groups in the rocks studied and, in this report, 


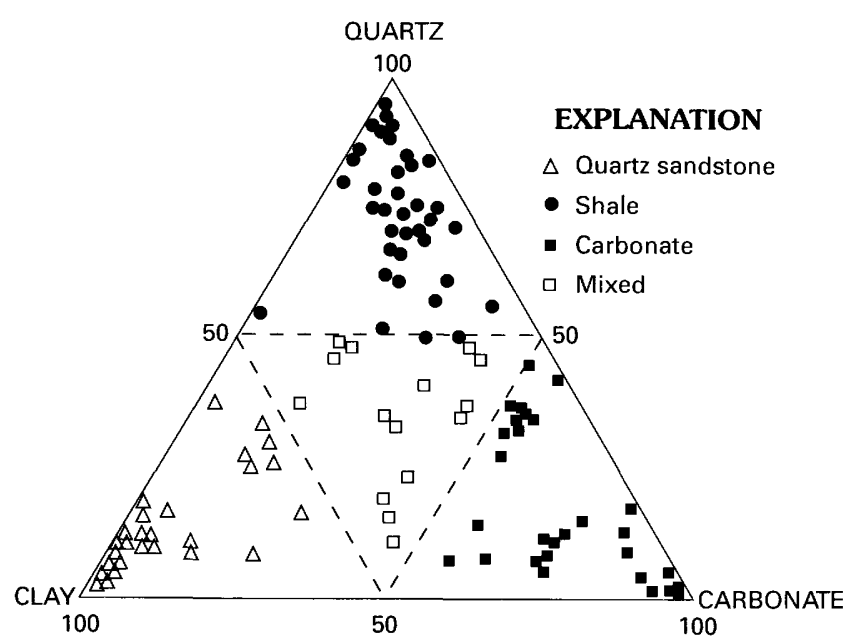

Figure 3. Ternary diagram showing mineral composition and lithology for samples of the Simpson Group from the Mazur well. Data in weight percent of bulk rock determined using $\mathrm{X}$-ray powder diffraction (XRD) analysis.

generally represent the pure end-member rock types quartz sandstone, shale, and carbonate rocks, respectively. Mineralogic compositions of Simpson Group rocks from the Mazur well are diverse and vary from almost pure endmember to mixed compositions.

Shale, as defined here using mineralogy, is composed predominantly ( $>50$ percent by weight) of clay minerals (phyllosilicates). Table 2 lists the average and range in composition for shale and sandstone of the Simpson Group from the Mazur well. As shown in the data of table 2 and illustrated in figure 3, the three main components of rocks in the Mazur well are quartz, clay, and carbonate. Shale in the well is unusually clay rich and quartz poor relative to data reported elsewhere for shale. In particular, shales from the Bromide, Tulip Creek, and upper part of the McLish, to a present depth of $16,400 \mathrm{ft}$ (interval 1 in table 2), have a mean composition of 84 percent clay and 7 percent quartz, by weight, as determined using XRD (table 1). Below this depth (interval 2), however, the Simpson Group shales contain more quartz and carbonate and have a mean composition of 62 percent clay, 15 percent quartz, and 13 percent carbonate. In both intervals feldspar and pyrite make up the remaining portion.

No good mineralogic data were found in the literature for other shallow-buried Paleozoic shales in the Anadarko basin for comparison. Therefore, the Mazur well shale data are compared to the mineralogic data of Hosterman and Whitlow (1983) for Devonian shales and bentonites of the Appalachian basin and to data of Schultz and others (1980) for Upper Cretaceous shales and bentonites of the Northern Great Plains (table 3). The data from Hosterman and Whitlow (1983) are from drill core and cuttings of Devonian shales, some of which have undergone significant burial diagenesis as evidenced by illite crystallinity and conodont color alteration indices. The data of Schultz and others (1980) from the Pierre Shale mainly represent outcrop samples that have not been significantly modified by burial diagenesis; some samples, however, have been altered by local thermal events. Also, these Upper Cretaceous shales were derived mainly from freshly altered volcanic debris (Schultz and others, 1980). In contrast, a shale mostly derived from reworked older detritus typically contains more quartz and fewer clay minerals.

The high clay and low quartz values for shales of the Simpson Group suggest that these shales were either primarily derived from altered volcanic debris (mainly glass), similar to the marine shale and bentonite of the Pierre Shale, or that the composition of the shales was modified by burial; that is, a significant amount of silica was removed from the shales by diagenetic processes. Similar high clay/quartz ratios are characteristic of bentonites, potassium bentonites, or tonsteins (Schultz and others, 1980; Pollastro, 1981; Hosterman and Whitlow, 1983; Pollastro and Martinez, 1985; Pollastro and Pillmore, 1987). In addition, pyrite is common in shales of the Simpson from this study and may account for as much as 20 weight percent of the whole-rock samples (table 1). Pyrite formation has been related to rocks derived from volcanic material (Schultz and others, 1980; Pollastro, 1981; Pollastro and Scholle, 1986).

No discrete volcanic ash layers were found in the Mazur core. Although there is no direct evidence that mineral assemblages of most or all of the shales of the Simpson were mostly products of altered volcanic debris, the Middle Ordovician of North America was a time of extensive explosive volcanic activity (Samson and others, 1989; Weaver, 1989) that presumably was related to Taconian orogenic activity. In eastern North America, at least 19 separate ash beds (a few centimeters to $4 \mathrm{~m}$ thick) have been identified in Middle Ordovician carbonate rocks (Weaver, 1989). Weaver (1989) stated that no discrete ash beds appear to have been preserved in the south-central region of North America; however, Middle Ordovician shales and limestones of Oklahoma and west Texas have a high I/S content. Weaver (fig. 9-1), using a compilation of clay mineral data for North American shales, showed that the amount of smectitic and chloritic clay minerals significantly increased during the Ordovician. He interpreted these minerals as volcanic in origin.

The present mineralogy of the Simpson shales may have been modified to some extent by burial diagenetic processes; that is, silica was removed from the shales during deep burial reactions. This interpretation, however, presents a problem of balancing the silica budget in the adjacent sandstones or other rock types analyzed because there is no petrographic evidence for extensive late silica cementation in adjacent sandstones. The silica budget has also been addressed by Boles and Franks (1979), Houseknecht (1988), and others. Silica expelled from shales during deep burial diagenesis and transported updip in solution may have provided a source for much earlier silica cement in sandstones at shallower depths. The silica in shales could 
Table 1. Mineralogical data from X-ray powder diffraction for samples from the Mazur well

In relative weight percent. Samples designated by depth from surface in feet and inches; number before decimal point indicates feet and after indicates inches. Asterisk (*) after sample designation indicates a shale sample. Bromide 1 and Bromide 2 are upper and lower units, respectively, of Bromide Formation and indicative of separate depositional cycles (Flores and Keighin, 1986). Sol carb, acid-soluble carbonate; Cal, calcite; Dol/Ank, dolomite and (or) ankerite; Plag, plagioclase; K-spar, potassium feldspar, I/S, illite/smectite; Kaol, kaolinite; Chl, chlorite; P, pyrite; F, fluorapatite; tr, trace; leaders $(-)$, none detected; nd, not determined]

\begin{tabular}{|c|c|c|c|c|c|c|c|c|c|c|c|c|}
\hline \multirow[b]{2}{*}{$\begin{array}{c}\text { Sample } \\
\text { designation }\end{array}$} & \multirow[b]{2}{*}{ Formation } & \multicolumn{7}{|c|}{ Whole-rock mineralogy } & \multicolumn{4}{|c|}{$<2-\mu m$ clay mineralogy } \\
\hline & & Clay & Quartz & $\mathrm{Cal}$ & DollAnk & Plag & K-spar & Other & Illite & us & $\mathrm{KaOl}$ & $\mathrm{Chl}$ \\
\hline $15917.3^{*}$ & Bromide $1 \ldots \ldots 13$ & 75 & 8 & 15 & 3 & -- & 3 & $3-\mathrm{P}$ & 49 & 49 & 1 & 1 \\
\hline 15923.3 & Bromide $1 \ldots . .50$ & 19 & 41 & 38 & 10 & -- & - & $2-\mathrm{P}$ & 31 & 66 & -- & 3 \\
\hline 15928.9 & Bromide $1 \ldots . .19$ & 32 & 47 & 15 & 5 & -- & -- & $1-\mathrm{P}$ & 27 & 62 & -- & 10 \\
\hline $15935.9 *$ & Bromide $1 \ldots . .24$ & 67 & 8 & 13 & 8 & -- & 2 & $2-\mathrm{P}$ & 33 & 62 & 3 & 3 \\
\hline 15947.9 & Bromide $1 \ldots . .54$ & 18 & 26 & 36 & 15 & -- & 3 & $2-\mathrm{P}$ & 41 & 52 & -- & 6 \\
\hline 15954.2 & Bromide $1 \ldots \ldots 63$ & 28 & 14 & 40 & 16 & 1 & -- & $1-\mathrm{P}$ & 40 & 56 & -- & 4 \\
\hline $15954.6 *$ & Bromide $1 \ldots \ldots .4$ & 80 & 9 & 1 & 9 & - & 4 & 4-P & 39 & 54 & 4 & 4 \\
\hline 15956.10 & Bromide $1 \ldots . .24$ & 14 & 56 & 23 & 5 & .. & -- & 2-P & 33 & 59 & -- & 8 \\
\hline 15959.6 & Bromide $1 \ldots .48$ & 13 & 28 & 44 & 4 & 7 & 3 & 1.P & 32 & 63 & -- & 5 \\
\hline 15966.1 & Bromide $1 \ldots \ldots 18$ & 34 & 47 & 9 & 9 & -. & -. & $1-\mathrm{P}$ & 51 & 44 & -- & 5 \\
\hline $15966.4^{*}$ & Bromide $1 \ldots \ldots 2$ & 86 & 8 & -- & -- & -- & 5 & -- & 46 & 48 & 3 & 3 \\
\hline 15978.5 & Bromide $1 \ldots . .39$ & 31 & 32 & 14 & 21 & -- & 1 & $1-\mathrm{P}$ & 42 & 53 & - & 5 \\
\hline 15986.9 & Bromide $1 \ldots \ldots 9$ & 5 & 85 & 1 & 9 & -- & - & - & 51 & 34 & -- & 15 \\
\hline 15955.7 & Bromide $1 \ldots . .30$ & 13 & 48 & 30 & 9 & -- & -- & -- & 28 & 41 & -- & 31 \\
\hline $16004.0^{*}$ & Bromide 1 .......... & 84 & 11 & - & - & -- & 5 & -- & 45 & 45 & -- & 11 \\
\hline 16016.2 & Bromide $1 \ldots . .36$ & 5 & 55 & - & 38 & -- & - & $2-P$ & 47 & 44 & -- & 9 \\
\hline $16030.5^{*}$ & Bromide 1 ........- & 89 & 7 & -- & - & -. & 3 & $1-\mathrm{P}$ & 44 & 46 & 5 & 5 \\
\hline 16032.2 & Bromide $1 \ldots . .20$ & 10 & 68 & -- & 20 & 2 & -- & $1-\mathrm{P}$ & 28 & 37 & -- & 35 \\
\hline $16038.6 *$ & Bromide 1 ........- & 92 & 3 & -- & $\cdots$ & - & 3 & $2-\mathrm{P}$ & 63 & 25 & 7 & 5 \\
\hline 16042.0 & Bromide $2 \ldots \ldots .7$ & 2 & 84 & -- & 14 & -- & - & -- & 10 & 12 & -- & 78 \\
\hline 16053.4 & Bromide $2 \ldots \ldots 16$ & 8 & 76 & -- & 8 & - & -- & -- & 50 & 43 & -- & 7 \\
\hline 16067.10 & Bromide $2 \ldots \ldots .4$ & 18 & 78 & -- & 4 & -- & -- & -- & 40 & 58 & - & 2 \\
\hline 16083.7 & Bromide $2 \ldots \ldots 17$ & 35 & 43 & -- & 18 & -- & -- & - & 43 & 50 & 4 & 3 \\
\hline $16097 / 98^{*}$ & Bromide $2 \ldots \ldots 6$ & 83 & 10 & -- & 3 & -- & 3 & $1-\mathrm{P}$ & 31 & 57 & 7 & 5 \\
\hline $16109 *$ & Bromide $2 \ldots . . .$. & 88 & 8 & -- & - & 1 & 3 & - & 65 & 27 & 4 & 4 \\
\hline 16112.3 & Bromide $2 \ldots . .71$ & 14 & 11 & 12 & 61 & -- & 2 & -- & 34 & 59 & -- & 6 \\
\hline 16225.2 & Tulip Creek.......-- & 4 & 96 & -- & -- & -- & -- & -- & 36 & 3 & - & 61 \\
\hline $16225.4^{*}$ & Tulip Creek.......- & 86 & 4 & -- & -- & -- & 5 & $5-P$ & 63 & 29 & -- & 7 \\
\hline 16230.6 & Tulip Creek.....tr & 15 & 85 & -- & $\operatorname{tr}$ & -- & tr & - & 56 & 2 & -- & 42 \\
\hline 16240.4 & Tulip Creek......tr & 14 & 84 & -- & $\operatorname{tr}$ & -- & tr & - & 49 & 13 & -- & 39 \\
\hline 16251.0 & Tulip Creek.... 20 & 7 & 70 & -- & 23 & -- & $\mathrm{tr}$ & -- & 46 & 10 & - & 44 \\
\hline 16263.1 & Tulip Creek......tr & 13 & 87 & -- & - & $\ldots$ & - & -- & 41 & 30 & -- & 29 \\
\hline 16273.4 & Tulip Creek...... 7 & 13 & 79 & 8 & -- & -- & -- & -- & 49 & 44 & -- & 7 \\
\hline 16289.9 & Tulip Creek.... 12 & 11 & 74 & -- & 15 & -- & - &.- & 83 & 17 & - & -- \\
\hline 16297.5 & Tulip Creek.... 18 & 20 & 60 & 16 & 2 & -- & 2 & - & 58 & 31 & -- & 11 \\
\hline 16302.11 & Tulip Creek.... 45 & 21 & 33 & 28 & 18 & .. & tr & -- & 61 & 37 & -- & 2 \\
\hline 16316.9 & Tulip Creek.... 85 & 6 & 9 & 2 & 82 & 1 & -- & - & 78 & 21 & -- & 1 \\
\hline $16318.3 *$ & Tulip Creek.... 10 & 82 & 2 & 2 & -- & -. & 4 & 4-P,8-F & 58 & 41 & -. & 1 \\
\hline 16327.9 & Tulip Creek.... 76 & -- & 19 & 1 & 80 & - & -- & -- & 79 & 21 & - & - \\
\hline $16328.4^{*}$ & Tulip Creek.......- & 58 & 2 & - & -. & -. & - & $12-\mathrm{P}, 28-\mathrm{F}$ & 56 & 44 & -- & - \\
\hline 16328.11 & Tulip Creek.... 55 & 10 & 34 & -. & 56 & -- & $\operatorname{tr}$ & -- & 80 & 20 & -- & -- \\
\hline 16338.8 & Tulip Creek... 17 & 16 & 67 & -- & 17 & -- & - & -- & 75 & 25 & -- & -- \\
\hline 16354.2 & Tulip Creek......9 & 14 & 74 & -- & 10 & -. & 2 & -- & 52 & 30 & -- & 18 \\
\hline $16358.4 *$ & Tulip Creek.......- & 80 & 16 & -- & - & -- & 3 & $1-\mathrm{P}$ & 84 & $1 ?$ & -- & 2 \\
\hline 16363.10 & Tulip Creek......4 4 & 4 & 91 & -- & 4 & -- & $\ldots$ & - & 35 & 35 & -- & 29 \\
\hline $16364.5 *$ & Tulip Creek......-- & 86 & 6 & -. & 1 & -- & -- & -- & 76 & 22 & -- & 2 \\
\hline
\end{tabular}

have been removed by organic fluids generated during the maturation of kerogen because these acidic pore fluids precede the migration of hydrocarbons (MacGowan and
Surdam, 1988). Houseknecht (1988) suggested that silica for early quartz overgrowths may have been transported in solution from deeper sandstones of the Bromide and other 
Table 1. Continued

\begin{tabular}{|c|c|c|c|c|c|c|c|c|c|c|c|c|}
\hline \multirow[b]{2}{*}{$\begin{array}{c}\text { Sample } \\
\text { designation }\end{array}$} & \multirow[b]{2}{*}{ Formation } & \multicolumn{7}{|c|}{ Whole-rock mineralogy } & \multicolumn{4}{|c|}{$<2-\mu m$ clay mineralogy } \\
\hline & & Clay & Quartz & $\mathrm{Cal}$ & Dol/Ank & Plag & K-spar & Other & Illite & $1 / 5$ & Kaol & $\mathrm{Chl}$ \\
\hline $16366.6^{*}$ & McLish............-- & 87 & 2 & 1 & 1 & 2 & 5 & $2-P$ & 77 & 22 & -- & 2 \\
\hline 16370.11 & McLish......... 12 & 10 & 78 & -- & 12 & -- & -- & -- & 88 & 12 & -- & -- \\
\hline 16382.9 & McLish......... 62 & 31 & 8 & 31 & 30 & -- & -- & -- & 49 & 42 & -- & 9 \\
\hline $16386.0^{*}$ & McLish.............- & 81 & 7 & -- & -- & -- & 5 & $1-\mathrm{P}$ & 71 & 29 & -- & -- \\
\hline 16396.7 & McLish............5 & 6 & 89 & -- & 5 & -- & -- & -- & 16 & 2 & -- & 82 \\
\hline $16402.0 *$ & McLish............-- & 86 & 5 & 2 & -- & 2 & 5 & 2-P & 86 & 12 & -- & 2 \\
\hline 16403.3 & McLish.........26 & 10 & 61 & 15 & 14 & -- & -- & -- & 59 & 13 & -- & 29 \\
\hline 16408.2 & McLish.......... 52 & 32 & 9 & 36 & 16 & 2 & 5 & -- & 58 & 37 & -- & 4 \\
\hline $16409.3 *$ & McLish............-- & 86 & 6 & -- & -- & 2 & 4 & 2-P & 83 & 16 & -. & 2 \\
\hline 16418.11 & McLish.......... 17 & 13 & 68 & 5 & 12 & -- & 2 & -- & 59 & 28 & -- & 13 \\
\hline 16428.9 & McLish........10 & 13 & 60 & 11 & 5 & 1 & 10 & -- & 65 & 25 & .. & 10 \\
\hline $16433.0 *$ & McLish............3 & 55 & 30 & - & 3 & -- & 10 & 2-P & 63 & 29 & -. & 8 \\
\hline $16441.2 *$ & McLish........... & 72 & 14 & 1 & 2 & -- & 7 & 2-P & 61 & 38 & -- & 2 \\
\hline 16443.7 & McLish..........39 & 31 & 22 & 34 & 5 & 2 & 4 & 2-P & 52 & 40 & -. & 7 \\
\hline $16445.5 *$ & McLish......... 14 & 50 & 29 & 12 & 3 & -- & 2 & 1-P & 69 & 28 & -- & 3 \\
\hline 16453.0 & McLish.........21 & 23 & 32 & 25 & 5 & 7 & 8 & -. & 54 & 36 & -- & 10 \\
\hline 16458.3 & McLish.........99 & 5 & 1 & 81 & 13 & -- & -- & -- & 63 & 33 & -- & 3 \\
\hline 16464.10 & McLish.........49 & 11 & 36 & 23 & 30 & -- & -. & -. & 92 & 8 & -- & -- \\
\hline $16472.8 *$ & McLish.............. & 62 & 3 & -- & -- & 3 & 26 & 5.P & 70 & 30 & -- & -- \\
\hline $16478.0 *$ & McLish...........4 & 73 & 9 & 2 & 2 & 2 & 9 & 3-P & 60 & 37 & -- & 3 \\
\hline 16476.8 & McLish.......... 39 & 16 & 33 & 30 & 13 & 3 & 2 & 3-P & 66 & 25 & -- & 9 \\
\hline 16487.7 & McLish.........55 & 33 & 10 & 35 & 15 & 3 & 4 & -- & 61 & 35 & -- & 4 \\
\hline 16496,6 & McLish..........98 & -- & 2 & 97 & 1 & -- & -- & -. & 31 & 63 & -- & 6 \\
\hline 16505.7 & McLish.........90 & -- & 5 & 86 & 6 & -- & 3 & -- & 50 & 48 & -- & 3 \\
\hline 16515.4 & McLish......... 99 & -- & 1 & 84 & 15 & -- & - & -- & 47 & 47 & -- & 6 \\
\hline 16525.2 & McLish..........95 & 6 & 2 & 70 & 22 & -- & -- & -- & 29 & 69 & -- & -- \\
\hline 16534.9 & McLish.........70 & 19 & 11 & 39 & 28 & -- & 3 & -- & 57 & 40 & -- & 3 \\
\hline 16544.3 & McLish.......... 31 & 23 & 36 & 15 & 16 & 2 & 8 & -- & 54 & 38 & -- & 8 \\
\hline 16551.10 & Oil Creek ......55 & 34 & 6 & 46 & 9 & 1 & 2 & 2-P & 48 & 51 & -- & 1 \\
\hline 16553.5 & Oil Creek .......99 & $\operatorname{tr}$ & $\operatorname{tr}$ & 95 & 4 & -- & -- & -- & 24 & 69 & -- & 7 \\
\hline $16554.0^{*}$ & Oil Creek .........5 & 77 & 9 & 2 & 5 & -- & 5 & 2-P & 80 & 20 & -- & -. \\
\hline 16566.8 & Oil Creek ......80 & 10 & 15 & 72 & 3 & -- & -. & -- & 69 & 31 & -. & -- \\
\hline 16578.5 & Oil Creek .......55 & -- & 26 & 46 & 11 & 8 & 9 & -- & nd & nd & nd & nd \\
\hline 16579.9 & Oil Creek ......15 & 41 & 33 & 8 & 8 & -- & 9 & 1-P & 53 & 41 & -- & 3 \\
\hline 16588.10 & Oil Creek .........34 & 14 & 49 & 31 & 6 & -- & -. &.- & 33 & 67 & -- & -- \\
\hline 16597.3 & Oil Creek .......36 & 12 & 46 & 25 & 17 & -- & -. & -- & 70 & 30 & -- & -- \\
\hline 16606.10 & Oil Creek ...... 52 & 12 & 33 & -- & 55 & -- & -- & -- & 56 & 44 & -. & -- \\
\hline 16616.8 & Oil Creek .........9 & 11 & 70 & -- & 11 & -- & -- & -- & 87 & 12 & -- & 2 \\
\hline 16624.6 & Oil Creek ........tr & 43 & 55 & -- & tr & -- & 2 & -- & 52 & 36 & -- & 11 \\
\hline $16626.8^{*}$ & Oil Creek ..........-- & 70 & 7 & -- & -- & -- & -. & 20-P & 76 & 18 & -- & 5 \\
\hline 16635.11 & Oil Creek ...... 18 & 18 & 61 & -. & 21 & -- & .. & -. & 42 & 31 & -- & 27 \\
\hline $16637.0 *$ & Oil Creek ...... 12 & 72 & 9 & -- & 10 & -- & 5 & 4-P & 78 & 19 & -- & 4 \\
\hline $16640.0^{*}$ & Oil Creek ........tr & 78 & 12 & .. & 2 & -- & 5 & 3-P & 80 & 17 & -- & 3 \\
\hline 16648.7 & Oil Creek ........2 & 7 & 90 & 3 & - & -- & -- & -- & 77 & 17 & -- & 5 \\
\hline $17056.5 *$ & Oil Creek ...... 13 & 55 & 24 & 11 & 3 & 2 & 2 & 3-P & 59 & 36 & -- & 5 \\
\hline $17057.4 *$ & Oil Creek ........6 & 76 & 15 & 2 & 2 & 1 & 3 & 3-P & 59 & 37 & -- & 4 \\
\hline 17058.10 & Oil Creek ......26 & 18 & 50 & 16 & 15 & -- & -. & -. & 39 & 53 & -- & 8 \\
\hline 17067.3 & Oil Creek .......79 & 19 & 7 & 70 & 2 & -- & -- & 2-P & 18 & 78 & -- & 4 \\
\hline
\end{tabular}

formations; he proposed, however, that the silica was derived from pressure solution of quartz grains.

Early quartz cement is pervasive in most sandstones of the Simpson of this study. Increased volcanic activity during the Middle Ordovician favored early quartz cementation because silica is released during the relatively rapid alteration of volcanic glass to clay, and both mineralogic and diagenetic evidence from the shale samples in the Mazur core favored some increased volcanic activity during Simpson deposition. This interpretation differs from that reported earlier by Pollastro (1989a). It is likely that both volcanic source material and diagenetic reactions involving 


\begin{tabular}{|c|c|c|c|c|c|c|c|c|c|c|c|c|c|}
\hline \multirow[b]{2}{*}{$\begin{array}{c}\text { Sample } \\
\text { designation }\end{array}$} & \multirow[b]{2}{*}{ Formation } & \multicolumn{8}{|c|}{ Whole-rock mineralogy } & \multicolumn{4}{|c|}{$<2-\mu \mathrm{m}$ clay mineralogy } \\
\hline & & $\begin{array}{c}\text { Sol } \\
\text { carb }\end{array}$ & Clay & Quartz & Cal & Dol/Ank & Plag & K-spar & Other & Illite & $1 / S$ & Kaol & $\mathrm{Chl}$ \\
\hline 17076.8 & Oil Creek.. &. .79 & 18 & 52 & 15 & 10 & 2 & - & 3-P & 49 & 42 & -- & 9 \\
\hline $17083.1 *$ & Oil Creek.. &. .25 & 52 & 15 & 8 & 17 & 2 & 2 & 4-P & 50 & 49 & -- & 2 \\
\hline 17086.3 & Oil Creek.. &. .73 & 17 & 11 & 53 & 17 & -. & -. & -- & 39 & 53 & -- & 9 \\
\hline 17099.2 & Oil Creek.. & ... 54 & 10 & 32 & 44 & 11 & -- & 3 & -- & 46 & 51 & -- & 4 \\
\hline 17106.7 & Oil Creek.. &. .82 & 4 & 13 & 71 & 14 & -- & -- & -- & 48 & 50 & -- & 3 \\
\hline 17115.0 & Oil Creek.. &. .67 & 28 & 7 & 32 & 27 & -. & 4 & 2-P & 64 & 34 & -- & 2 \\
\hline 17115.8 & Oil Creek.. &. .37 & 38 & 18 & 6 & 30 & -- & 3 & 2-P & 73 & 26 & -- & 1 \\
\hline 17116.2 & Oil Creek.. &. .49 & 5 & 42 & 27 & 24 & 2 & -- & $\therefore$ & 65 & 35 & -- & -- \\
\hline 17130.3 & Oil Creek.. &. .10 & 5 & 83 & 1 & 11 & - & -- & .- & 69 & 31 & -- & -- \\
\hline 17136.3 & Oil Creek.. & $\ldots .7$ & 8 & 82 & -- & 10 & -- & -- & -- & nd & nd & nd & nd \\
\hline 17147.1 & Oil Creek. &. .20 & 4 & 75 & -- & 21 & -- & -- & -- & 84 & 16 & -- & -- \\
\hline 17159.11 & Oil Creek.. & ....tr & 5 & 93 & 2 & -- & -. & -- & -. & 73 & 27 & -- & -- \\
\hline 17172.7 & Oil Creek .. & ....tr & 8 & 82 & -- & - & -- & -- & -- & 77 & 23 & -- & -- \\
\hline 17182.10 & Joins ........ &. .20 & 8 & 72 & .- & 20 & .. & -- & .- & 88 & 12 & -. & -- \\
\hline $17184.6^{*}$ & Joins ........ &. .14 & 55 & 23 & 6 & 9 & -- & 4 & 3-P & 68 & 31 & -- & 1 \\
\hline 17184.9 & Joins ........ &. .22 & 5 & 71 & 23 & 1 & -- & -- & -- & nd & nd & nd & nd \\
\hline 17190.10 & Joins ........ &. .76 & 22 & 5 & 4 & 67 & -. & 2 & -. & 48 & 50 & -- & 2 \\
\hline 17217.5 & Joins ....... &. .44 & 41 & 10 & 25 & 17 & 1 & 3 & 3-P & 52 & 46 & -- & 2 \\
\hline
\end{tabular}

Table 2. Range and mean whole-rock mineralogic composition for 36 samples of shale and 50 samples of sandstone from the Mazur well

[Determined using $\mathrm{X}$-ray powder diffraction in weight percent of whole rock. Shale interval 1 refers to Bromide, Tulip Creek, and upper part of McLish Formations to core depth of $16,400 \mathrm{ft}$, interval 2 includes Simpson Group shales between 16,400 and 17,400 ft]

\begin{tabular}{lrrrrr}
\hline \multicolumn{3}{c}{ Interval 1 } & \multicolumn{2}{c}{ Interval 2 } & \multicolumn{2}{c}{ Sandstone } \\
\multicolumn{1}{c}{ Range } & Mean & \multicolumn{1}{c}{ Range } & Mean & Range & Mean \\
\hline Quartz .........2-11 & 7 & $3-33$ & 15 & $50-96$ & 66 \\
Clay ..........58-92 & 84 & $41-78$ & 62 & $2-35$ & 14 \\
Carbonate.... 0-21 & 3 & $0-42$ & 13 & $0-48$ & 18 \\
Feldspar...... 0-7 & 4 & $0-27$ & 6 & $0-15$ & 2 \\
Pyrite......... 0-14 & 3 & $1-20$ & 4 & $0-3$ & $<1$ \\
\hline
\end{tabular}

transportation of silica may have produced the present mineralogy of shales of the Simpson Group from the Mazur well.

The whole-rock XRD mineralogical compositions of 50 sandstone samples from the Simpson Group in the Mazur well are also summarized in table 1. Sandstones average 66 percent quartz, by weight; some sandstones from the Oil Creek and Tulip Creek Formations contain as much as 96 percent quartz. All sandstone samples, other than a few almost pure ones, contain appreciable clay and carbonate minerals, averaging 14 and 18 weight percent, respectively. Feldspar content is about 2 weight percent and pyrite less than 1 percent. The whole-rock XRD data are in close agreement with thin section point counts of this report (see following section) and with data for the McLish Formation reported by Weber (1987).

\section{Sandstone Petrology}

\section{Composition and Porosity}

Point-count analysis for 32 sandstone samples is summarized in table 4; framework compositions are plotted on the quartz-feldspar-rock fragments ternary diagram of figure 4. Most sandstones are quartzarenite; some subfeldspathic arenites are in the Tulip Creek and Mclish Formations and one sandstone from the Tulip Creek Formation is a sublithic arenite. Sandstones are composed mainly of detrital monocrystalline quartz grains (fig. $5 A$ ) and generally less than 5 percent feldspar, most of which is potassium feldspar (fig. $5 B$ ). Three sandstones, two from the Oil Creek and one from the Bromide, are graywackes (fig. $5 C$ ).

Lithic framework grains are principally shale clasts that are sometimes partly dissolved (fig. $5 D$ ). Carbonate clasts and shell fragments are present in a few samples; chert is extremely rare. Petrographic analysis indicates that most sandstones are mineralogically mature to supermature.

Most sandstones contain little or no porosity. All porosity observed in thin section is secondary (dissolution) porosity and is best developed in the Tulip Creek and Oil Creek Formations. Sandstones of these formations contain as much as 11 percent porosity, mainly secondary and intergranular, as determined from point-count analysis (figs. $5 B$ and $6 A$ ). Minus-cement porosity determined from point-count analysis is commonly high (figs. $6 B$ and $C$ ) and in some cases exceeds 40 percent. Some intragranular (moldic) porosity is also present (fig. 5D). Secondary intergranular porosity is mainly from the dissolution of 
Table 3. Comparison of average mineralogic composition of Simpson Group shale from the Mazur well and typical shale and bentonite

[Values in weight percent of bulk rock]

\begin{tabular}{|c|c|c|c|c|c|}
\hline & \multicolumn{2}{|c|}{ Cretaceous shale ${ }^{2}$} & \multirow{2}{*}{$\begin{array}{l}\text { Cretaceous } \\
\text { bentonite }\end{array}$} & \multirow{2}{*}{$\begin{array}{c}\text { Devonian } \\
\text { shale }^{4}\end{array}$} & \multirow{2}{*}{$\begin{array}{l}\text { Devonian } \\
\text { potassium } \\
\text { bentonite }\end{array}$} \\
\hline shale $^{1}$ & Marine & Nonmarine & & & \\
\hline Quartz......................11 & 22 & 25 & 2 & 23 & 10 \\
\hline Clay minerals .............74 & 68 & 61 & 83 & 66 & 83 \\
\hline Carbonate minerals ........7 & 2 & 7 & 3 & 8 & 1 \\
\hline Feldspar...................4 & 5 & 7 & 4 & Minor & 2 \\
\hline Other....................... & 3 & Minor & Minor & 3 & 4 \\
\hline
\end{tabular}

\footnotetext{
1 Determined using $X$-ray powder diffraction.

2 Data from Schultz and others (1980) for 366 samples of "ordinary shale" of the Pierre Shale and equivalent rocks, Northern Great Plains.

${ }^{3}$ Data from Schultz and others (1980) for 119 samples of marine bentonite of the Pierre Shale and equivalent rocks, Northern Great Plains.

${ }^{4}$ Data from Hosterman and Whitlow (1983) for about 1800 samples of Devonian shale from drill core and cuttings $(0-14,500 \mathrm{ft})$, Appalachian basin.

${ }^{5}$ Data from Hosterman and Whitlow (1983) for 9 samples of ash beds of Devonian shale from drill core and cuttings (675-7,500 ft), Appalachian basin.
}

carbonate cements, as evidenced by irregular and etched quartz framework grains and small remnants of earlier intergranular carbonate cement (figs. $5 B$ and 6A). The shape and oversize of intergranular areas containing carbonate cement and the high percentage of carbonate in some of the sandstones (figs. $5 A, 9 A, B$ ) suggest that labile grains such as plagioclase or rock fragments once occupied some of these spaces. Thus, these sandstones may not have been as quartz rich as they are today.

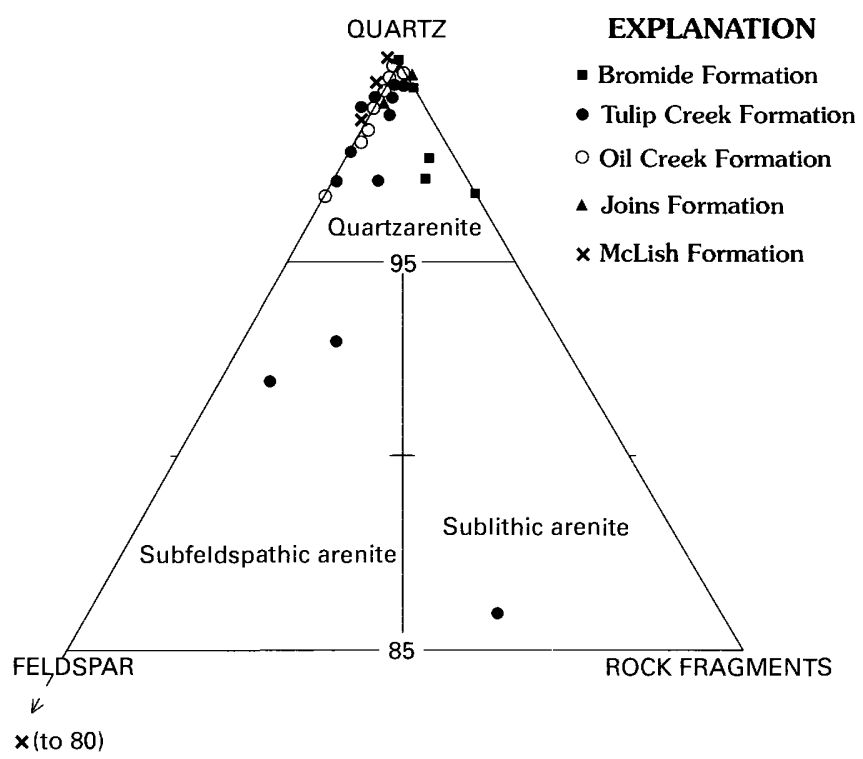

Figure 4. Partial ternary diagram showing composition of sandstones of the Simpson Group from the Mazur well determined using point-count analysis (minimum 300 counts). Sandstone classification scheme modified from Pettijohn and others (1973).

\section{Diagenesis}

The paragenetic sequence interpreted for sandstones of the Simpson Group in the Mazur well is shown in figure 7. It should be noted, however, that the extent of diagenesis varies from one sandstone to another. Many of the diagenetic stages interpreted here are similar to those reported by Weber (1987), Pitman and Burruss (1989), and Pollastro (1989a). Although the relative timing of each event is shown in figure 7 , the diagenesis in these sandstones can be grouped into three stages: early, intermediate, and late.

Early diagenesis is characterized by the formation of framboidal pyrite (fig. $8 A$ ), dissolution of labile grains (probably plagioclase and rock fragments, fig. $5 D$ ), and cementation by iron-poor calcite (fig. $6 B$ ) or syntaxial quartz overgrowths (figs. $6 C, D, 8 B$ ). Criteria for the dissolution of labile grains include oversize pores now filled with calcite and some floating grains (figs. $5 A$ and $6 B$ ). Although cementation by calcite and quartz is believed to have occurred relatively early in the burial history, grain contacts average about three per grain. This criteria and the presence of longitudinal- and interpenetrative-grain contacts (figs. $5 A$ and $6 C$ ) suggest that at least $3,300 \mathrm{ft}$ of burial occurred before cementation (Taylor, 1950; Pettijohn, 1975).

Intermediate events include the dissolution and (or) replacement of clay as matrix or rock fragments, conversion of smectite to illite, overgrowths on potassium feldspar grains, replacement or conversion of iron-poor calcite to iron-rich calcite, dissolution of calcite cements, and formation of dolomite cement. Iron-rich calcite commonly replaces or encompasses earlier iron-poor calcite, as evidenced from stained thin sections (fig. 9A). Iron-rich carbonate cements formed after quartz overgrowths (fig. $9 B$ ). Dissolution of intergranular calcite cements commonly 
Table 4. Point-count compositional analysis of 32 thin sections of sandstone from the Mazur well [Data based on a minimum of 300 counts per section. Framework components in percent of total framework content; pores and pore fillers in percent of total rock. Depth designation in feet.inches, see table 1]

\begin{tabular}{|c|c|c|c|c|c|c|}
\hline \multirow[b]{2}{*}{ Depth } & & \multicolumn{2}{|c|}{ Framework components } & \multicolumn{3}{|c|}{ Pores and pore fillers } \\
\hline & Formation & Feldspar & Rock fragments & Matrix & Cement & Porosity \\
\hline $15,928.9$ & Bromidc..................96 96 & 0 & 4 & 16 & 18 & 0 \\
\hline $15,956.10$ & Bromide.................97 & 1 & 2 & 3 & 28 & 0 \\
\hline $15,986.9$ & Bromide.................100 & 0 & 0 & 0 & 22 & 0 \\
\hline $16,042.0$ & Bromide...................97 & 1 & 2 & 0 & 21 & 0 \\
\hline $16,053.4$ & Bromide....................99 & 0 & 1 & 0 & 26 & 0 \\
\hline $16,067.10$ & Bromide..................97 97 & 0 & 3 & 1 & 13 & 2 \\
\hline $16,225.2$ & Tulip Creck...............99 & 1 & 0 & 0 & 6 & 8 \\
\hline $16,230.6$ & Tulip Creek................999 & 1 & 0 & 0 & 4 & 11 \\
\hline $16,240.4$ & Tulip Creck...............97 & 3 & 0 & 0 & 6 & 8 \\
\hline $16,251.0$ & Tulip Creck...............98 & 2 & 0 & 0 & 20 & 0 \\
\hline $16,263.0$ & Tulip Creek.............100 & 0 & 0 & 0 & 14 & 3 \\
\hline $16,273.4$ & Tulip Creek..............99 & 1 & 0 & 1 & 24 & 1 \\
\hline $16,289.9$ & Tulip Creek................999 & 1 & 0 & 0 & 22 & 0 \\
\hline $16,297.5$ & Tulip Creck..............97 & 2 & 1 & 5 & 28 & 0 \\
\hline $16,302.11$ & Tulip Creck..............992 & 7 & 1 & 6 & 40 & 0 \\
\hline $16,338.8$ & Tulip Creek..............100 & 0 & 0 & 1 & 28 & $<1$ \\
\hline $16,354.2$ & Tulip Creek............... 86 & 5 & 9 & 1 & 21 & 1 \\
\hline $16,363.10$ & Tulip Creck..............93 & 5 & 2 & 1 & 19 & $<1$ \\
\hline $16,370.11$ & McLish.................... 99 & 1 & 0 & 1 & 29 & 0 \\
\hline $16,403.11$ & McLish.................100 & 0 & 0 & 5 & 33 & 0 \\
\hline $16,418.11$ & McLish..................... 98 & 2 & 0 & 5 & 33 & 0 \\
\hline $16,428.9$ & McLish................... 80 & 20 & 0 & 2 & 18 & 0 \\
\hline $16,616.8$ & Oil Creek ................... 98 & 2 & 0 & 5 & 31 & 0 \\
\hline $16,624.6$ & Oil Creck .................99 & 1 & 0 & 29 & $<1$ & 0 \\
\hline $16,635.11$ & Oil Creck .................100 & 0 & 0 & 9 & 22 & 1 \\
\hline $16,648.7$ & Oil Creek ....................999 & 1 & 0 & 2 & 6 & 3 \\
\hline $17,058.10$ & Oil Crcek .................100 & 0 & 0 & 19 & 28 & 0 \\
\hline $17,130.3$ & Oil Creek .................999 & 1 & 0 & 0 & 29 & 0 \\
\hline $17,136.3$ & Oil Creek .................98 & 2 & 0 & 0 & 17 & $<1$ \\
\hline $17,147.1$ & Oil Creek ..................999 & 1 & 0 & 0 & 39 & $<1$ \\
\hline $17,159.11$ & Oil Creck ................. 97 & 3 & 0 & 0 & 12 & 7 \\
\hline $17,172.7$ & Oil Creek ................. 100 & 0 & 0 & 0 & 8 & 4 \\
\hline $17,182.0$ & Joins .....................999 & 1 & 0 & 0 & 27 & 0 \\
\hline $17,184.9$ & Joins ...................100 & 0 & 0 & 0 & 15 & 1 \\
\hline
\end{tabular}

created secondary porosity (fig. $5 B$ ). In many sandstones potassium feldspar overgrowths developed on detrital potassium feldspar grains (figs. $5 D$ and $9 C$ ). The potassium for overgrowth cement may have come from dissolved or replaced potassium feldspar in adjacent sandstones (fig. $6 \mathrm{~A}$ ), local potassium-bearing matrix clay (fig. $9 \mathrm{C}$ ), or clayrich rock fragments (fig. 5D) that were dissolved or replaced. Illitization of smectite begins during intermediate stages of burial when temperatures approach $60^{\circ} \mathrm{C}$ (Hoffman and Hower, 1979). Pore-lining or grain-coating chlorite was also precipitated during intermediate stages of burial in sandstones lacking early quartz or calcite cements (fig. 10A).

Late diagenetic events include the formation of ferroan dolomite and ankerite (fig. 9D) and some quartz cement, some dissolution of iron-bearing carbonate minerals, progressive illite growth or sericitization of earlier I/S (fig. 11A) (Pollastro, 1989b), and conversion of kaolinite to chlorite. These events will be discussed in later sections of this report. The formation of these later diagenetic phases is consistent with the diagenetic model proposed by Surdam and others (1989), for which burial temperatures exceeded $120^{\circ} \mathrm{C}$.

\section{Clay Mineralogy}

The clay mineralogy of sandstones and shales from the Mazur well is summarized in table 5; quantitative clay analysis of the $<2-\mu \mathrm{m}$ fraction for individual samples is given in table 1. Carbonate rocks have a clay-mineral assemblage similar to that of shale. The dominant clay mineral is illite (as defined below); authigenic iron-rich chlorite is locally concentrated in sandstone. Minor to trace 
Table 5. Average clay-mineral composition and range for 62 samples of shale and carbonate rocks and 50 samples of sandstone from the Simpson Group in the Mazur well

[Values in relative weight percent of clay minerals in $<2-\mu \mathrm{m}$ fraction. I/S indicates ordered illite/smectite]

\begin{tabular}{|c|c|c|c|}
\hline & Shale and carbonate & \multicolumn{2}{|c|}{ Sandstone } \\
\hline Mean & Range & Mean & Range \\
\hline $\begin{array}{l}\text { Illite } \\
\quad(\text { illite }+I / S) \ldots \ldots \ldots 96\end{array}$ & $88-100$ & 85 & $18-100$ \\
\hline Iron chlorite.............4 & $0-11$ & 15 & $0-82$ \\
\hline Kaolinite. & $0-7$ & $<1$ & $0-4$ \\
\hline
\end{tabular}

amounts of kaolinite are present in some samples above $16,300 \mathrm{ft}$; kaolinite is absent below this depth.

Almost all samples contain more than 90 percent illitic clay minerals in the $<2-\mu \mathrm{m}$ fraction. Illitic clay minerals include both discrete illite (10 angstrom) and I/S. All I/S in rocks of the Simpson Group from the Mazur well
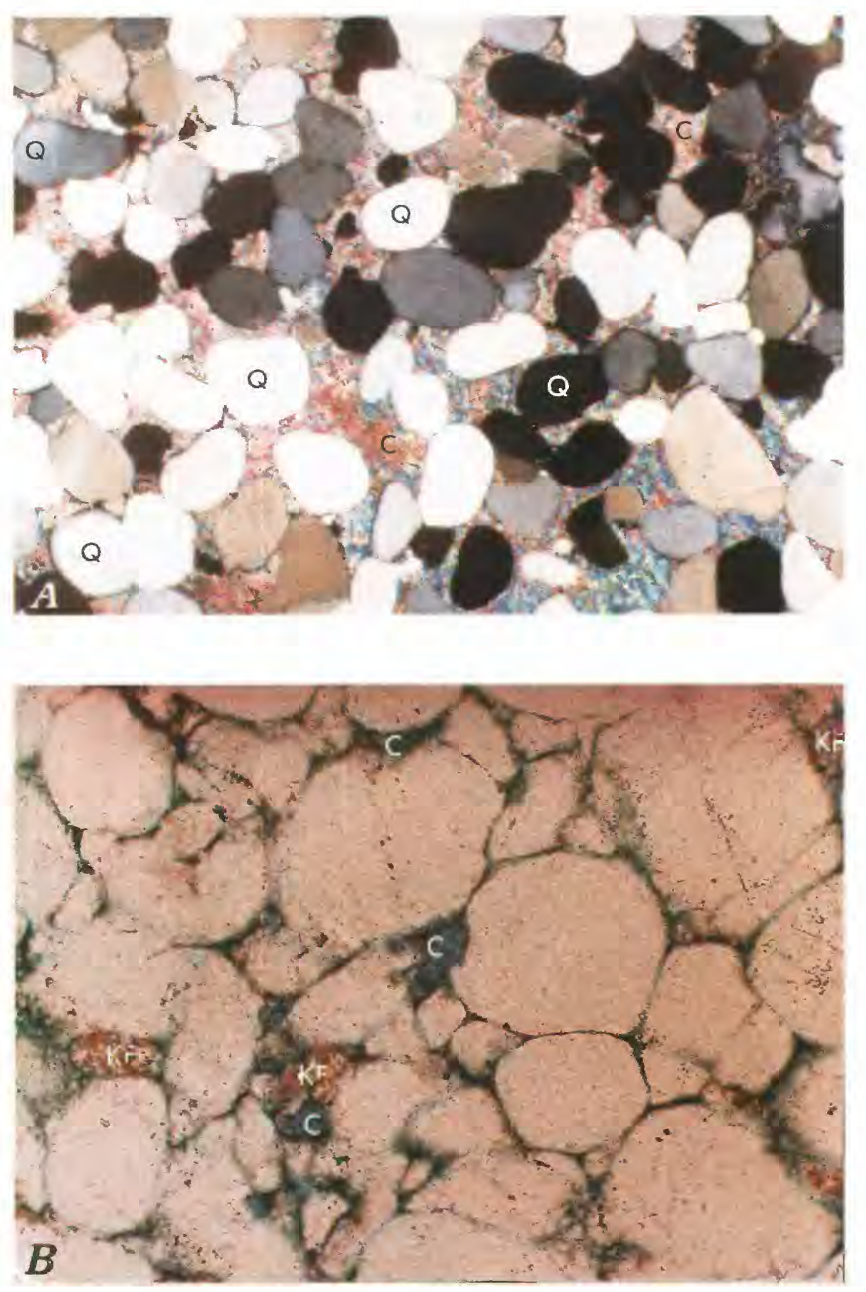

is regularly interstratified $I / S(R \geq 1)$, and most samples contain only $\mathrm{I} / \mathrm{S}$ with $\mathrm{R} \geq 3$ ( $<15$ percent expandable layers) (fig. 12), as defined by XRD profiles using the XRD interpretive methods of Reynolds and Hower (1970). Following the concept of fundamental particles and interparticle diffraction (Nadeau and others, 1984a, b, 1985), however, ordered I/S is defined here as "thin" illite crystals 20-50 angstroms thick (apparent I/S in fig. 12). I/S clay in table 1 was, therefore, recalculated as "illite" (illite=discrete illite and $\mathrm{I} / \mathrm{S}$ ) in the data of table 5.

The average clay-mineral composition of shale and carbonate rocks from the Mazur well is about 96 relative weight percent illite and 4 percent chlorite, as determined using XRD (table 4). The chlorite in shale probably reflects a relatively constant, but minor, influx of detrital chlorite.

The average clay-mineral composition of sandstone from the Mazur well is 85 percent illite and 15 percent
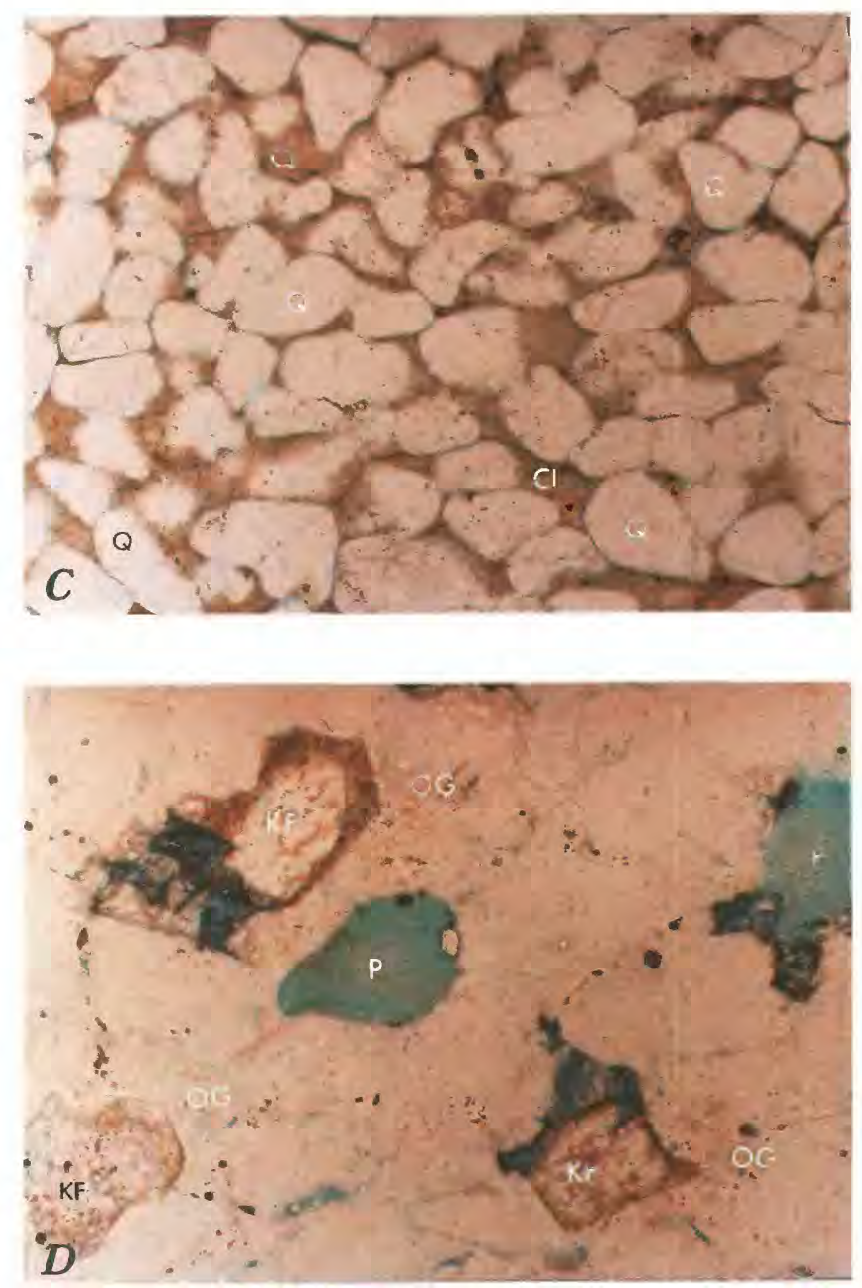

Figure 5. Thin section photomicrographs of sandstones of the Simpson Group from the Mazur well. Scale bars are 0.2 mm. A, Monocrysta!line quartz (Q) grains in calcite-cemented (C) sandstone. Tulip Creek Formation, 16,251 ft; crossed nicols. B, Blueepoxy-impregnated sandstone showing remnants of carbonate (C) cement and detrital potassium feldspar (KF) grains. Tulip Creek Formation, 16,240 ft. C, Quartz (Q) wacke and interstitial clay $(\mathrm{Cl})$. Oil Creek Formation, 16,624 ft. D, Sublithic arenite showing intragranular porosity $(\mathrm{P})$ from the dissolution of shale clasts. Note overgrowths (OG) on detrital potassium feldspar (KF) grains. Tulip Creek Formation, 16,354 ft. 

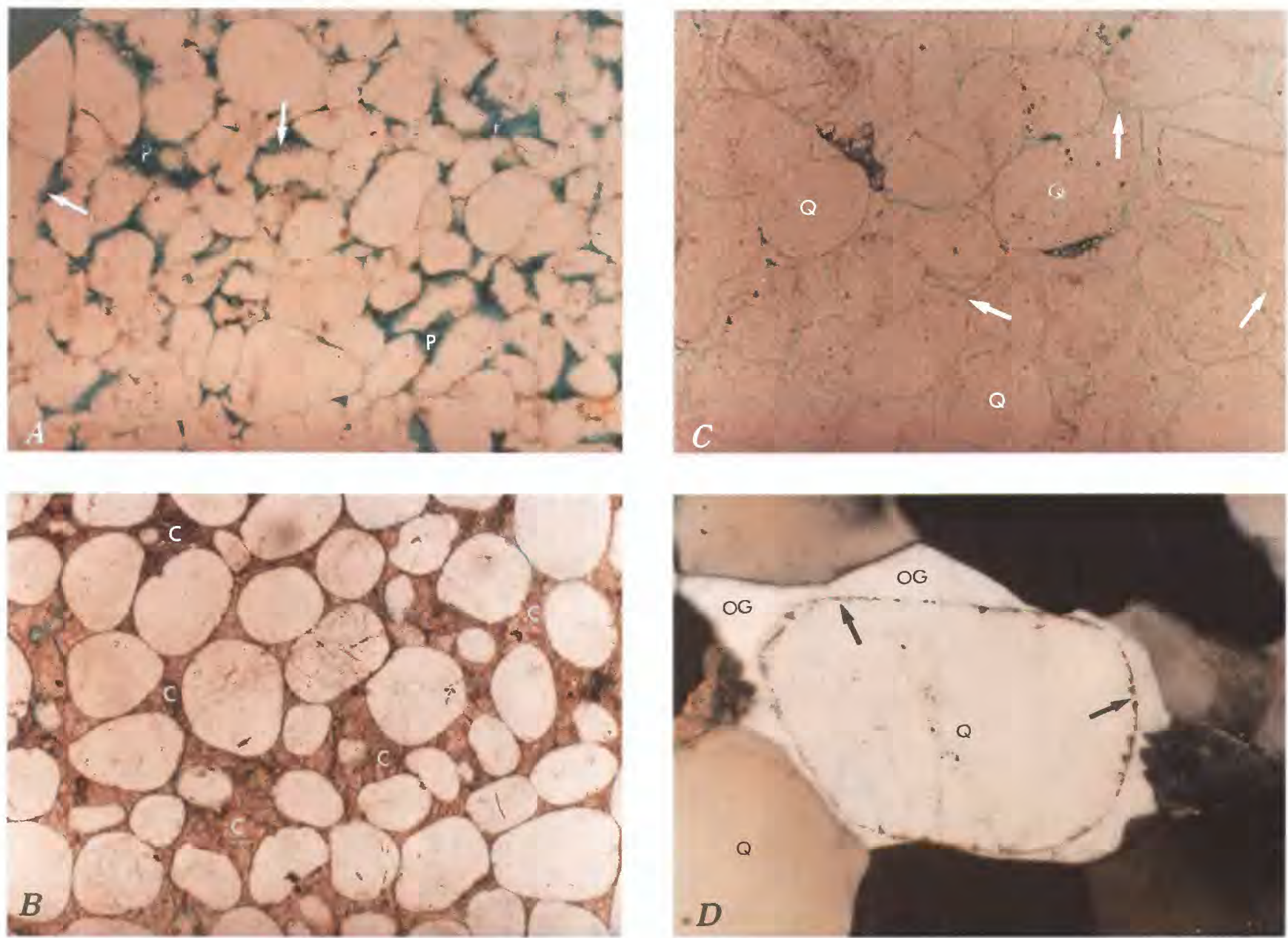

Figure 6. Thin section photomicrographs of quartzarenites of the Simpson Group from the Mazur well. Scale bars are 0.2 mm. A, Blue-epoxy-impregnated sandstone showing intergranular porosity $(\mathrm{P})$ and etched surfaces (arrows) of quartz framework grains that probably are the result of dissolution of an earlier intergranular carbonate cement. Tulip Creek Formation, 16,230 ft. B, High minus-cement porosity in sandstone cemented by iron-free calcite (C). Bromide Formation, 15,929 ft. C, Quartz-cemented sandstone showing extensive overgrowths (arrows) on detrital quartz (Q) grains. Tulip Creek Formation, 16,264 ft. D, Detrital quartz (Q) grain showing well-defined dust rim (arrows) and extensive overgrowths (OG). Bromide Formation, 16,042 ft; crossed nicols.

chlorite. Local concentrations of authigenic iron-rich chlorite may account for as much as 82 percent of the clay minerals in the $<2-\mu \mathrm{m}$ fraction (table 1 ), but many samples contain little or no chlorite.

\section{Clay Diagenesis}

Clay minerals in these deeply buried rocks of the Simpson Group are essentially illite, apparent $I / S(R \geq 1)$, and chlorite. Kaolinite is present in only minor amounts. There is a distinct absence or disappearance of kaolinite below about $16,300 \mathrm{ft}$ in the well. The present clay mineralogy of the Simpson Group in the Mazur well is consistent with an assemblage that is mostly the result of deep burial diagenesis. Further evidence for this interpretation is provided by XRD and SEM analyses and burial-history reconstructions.
The major clay-mineral reaction that occurs during the progressive burial of sedimentary rocks is the conversion of smectite to illite (Hower, 1981), a reaction illustrated and partly reinterpreted by Pollastro (1985, p. 273, fig. 8). Smectite (or smectite layers in $\mathbf{I} / \mathbf{S}$ ) in sediment or rock at near-surface or shallow-burial conditions is converted to illite (or illite layers in I/S) under increased temperature $\left(>60^{\circ} \mathrm{C}\right)$ and pressure (?) due to burial depth (Hower and others, 1976). Boles and Franks (1979) and Pollastro $(1983,1985)$ proposed that the reaction involves, in part, the dissolution of smectite, conservation of aluminum and potassium, and precipitation of illite. Calcium. silica, iron, and magnesium are released from smectite in the reaction. These elemental reaction products combine to form, at least in part, authigenic mineral phases in pores or fractures of deeply buried rocks. Typical phases that may form include dolomite, fine-grained quartz or 


\begin{tabular}{|l|l|}
\hline \multicolumn{1}{|c|}{ DIAGENETIC STAGE } & Early \\
\hline Pyrite formation \\
Labile grain dissolution \\
Quartz cement \\
Calcite cement \\
Potassium feldspar overgrowths \\
Calcite to iron calcite \\
Smectite to illite \\
Clay matrix dissolution and replacement \\
Iron dolomite and ankerite \\
Chlorite cement \\
IIlite overgrowths and sericitization \\
Grain dissolution \\
Kaolinite to chlorite
\end{tabular}

Figure 7. Paragenetic sequence for sandstones of the Simpson Group in the Mazur well.
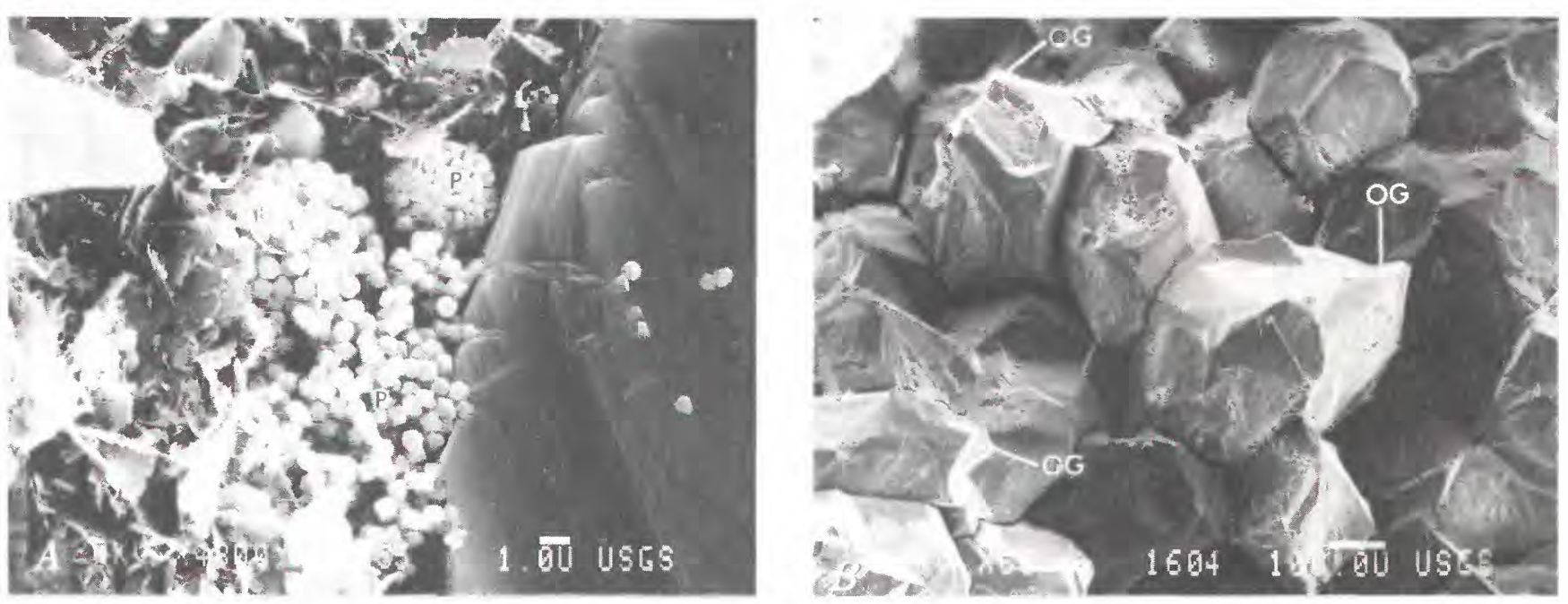

Figure 8. Scanning electron micrographs of sandstones of the Simpson Group from the Mazur well. Scale bars are $10 \mu \mathrm{m}$. A, Authigenic framboidal pyrite $(\mathrm{P})$ in sandstone. B, Overgrowth (OG) cement on detrital quartz grains in quartzarenite.

quartz overgrowth cement, chlorite, and illite cement or overgrowths (Boles and Franks, 1979; McHargue and Price, 1982; Pollastro, 1985). In open systems, however, these elements may leave the system completely and not necessarily result in the immediate in situ precipitation of authigenic minerals.

XRD profiles interpreted using the interparticle diffraction concept indicate that no true smectite is present in the Simpson Group rocks from the Mazur well. In addition, morphological evidence from SEM observations suggests that any earlier smectite-bearing clay has been converted to illite. This is evidenced by textures similar to those described by Pollastro (1985) from SEM analysis in which intergrowths and overgrowths of tabular fibers of illite are superimposed within or on a honeycomb or cornflake morphology. Such textures suggest that an earlier smectiterich clay was recrystallized during diagenesis and converted to illite.

Sandstone from the Mazur well commonly contains authigenic illitic clay cements. Many of these cements were precipitated as illite late in the burial history; however, some of the cement was probably once smectitic and later converted to illite under relatively deep burial conditions. Figure $13 A$ shows a scanning electron micrograph of a clay 

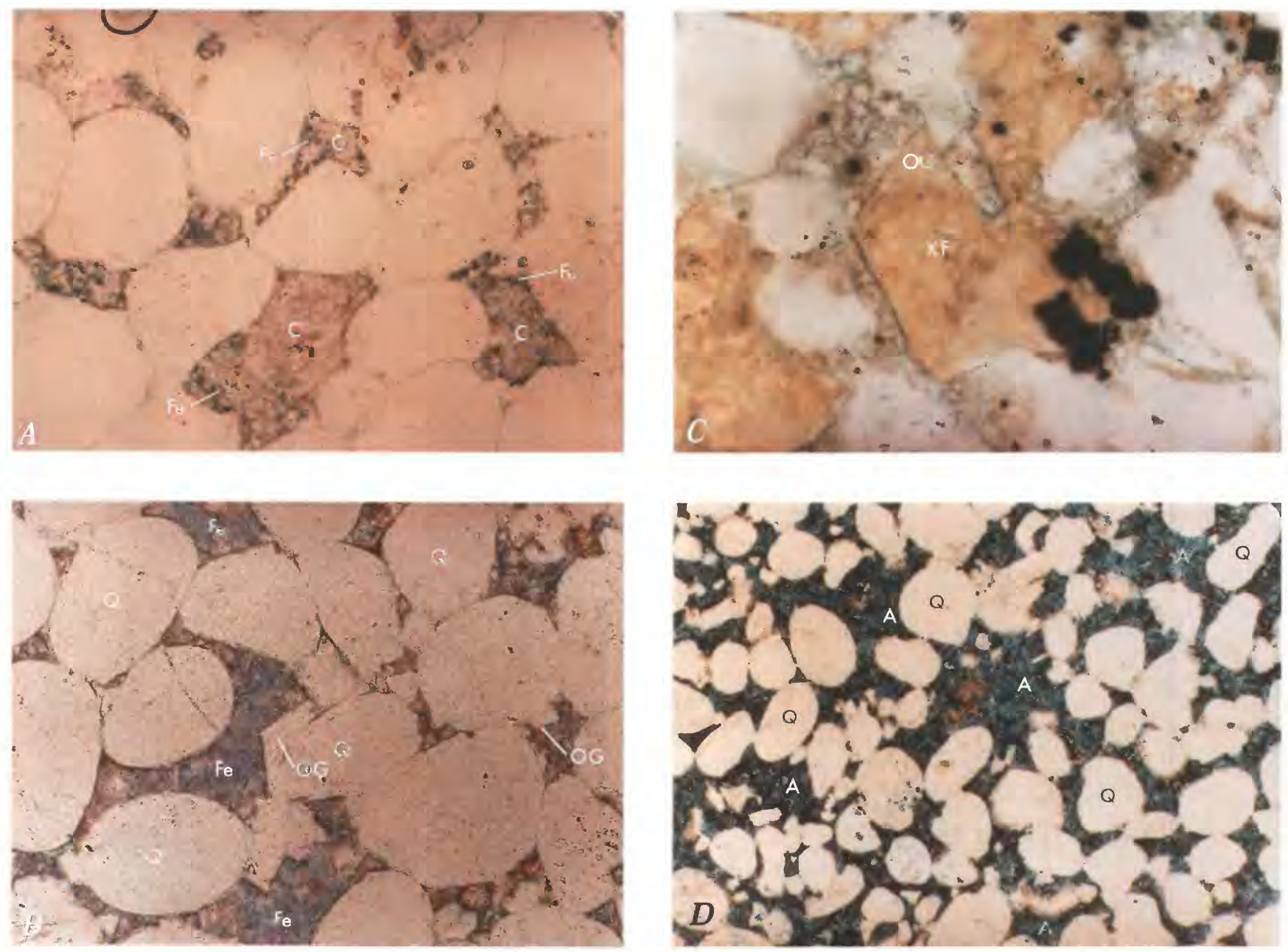

Figure 9. Thin section photomicrographs of sandstones of the Simpson Group from the Mazur well. Scale bars are 0.2 mm. A, Iron-rich (Fe) calcite encompassing or replacing earlier iron-poor (C) calcite. Tulip Creek Formation, 16,273 ft. B, Overgrowth cement (OG) on detrital quartz (Q) grains interpreted to have formed prior to iron-rich calcite (Fe) cement. Tulip Creek Formation, 16,251 ft. Cr Stained overgrowths (OG) of potassium feldspar on detrital potassium feldspar (KF) grain. McLish Formation, 16,433 ft. D. Ankerite (A) cement replacing quartz (Q) framework grains, cement, and clay. Bromide Formation, $16,016 \mathrm{ft}$.
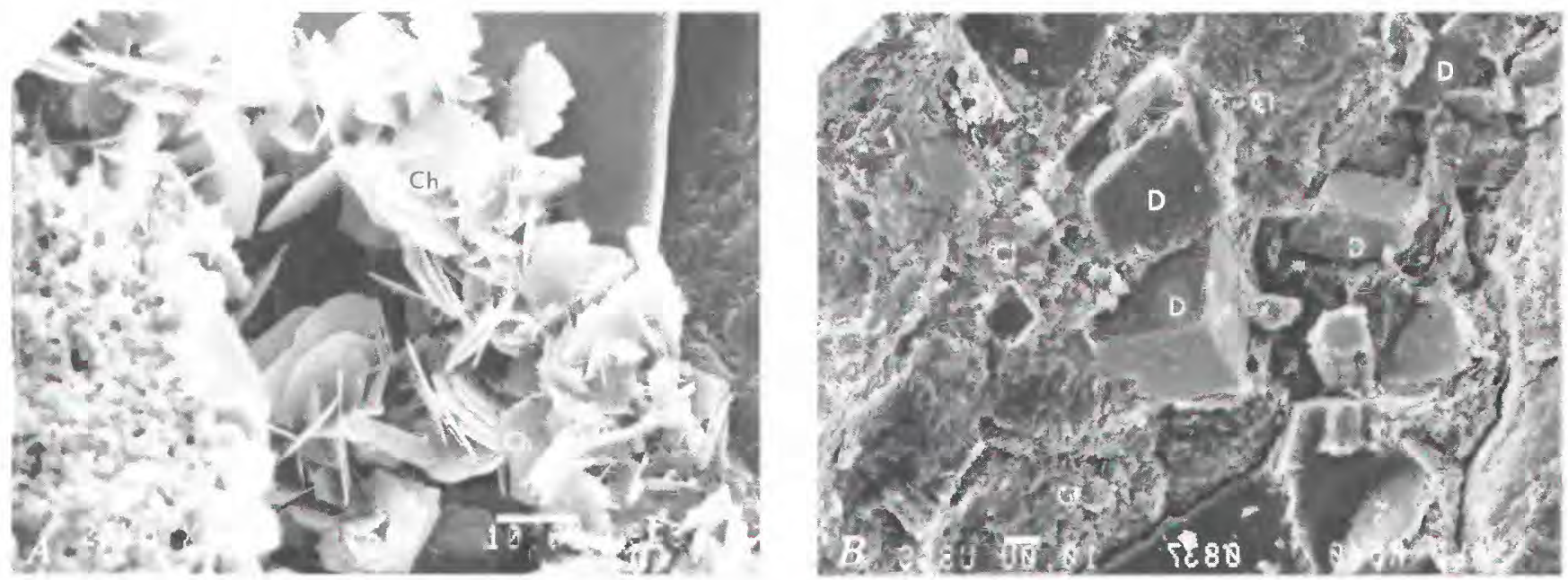

Figure 10. Scanning electron micrographs of sandstones of the Simpson Group from the Mazur well. Scale bars are $10 \mu \mathrm{m}$. $A$, Authigenic pore-lining chlorite $(\mathrm{Ch})$ in sandstone. B, Dolomite (D) replacing detrital clay $(\mathrm{Cl})$ in sandstone. 

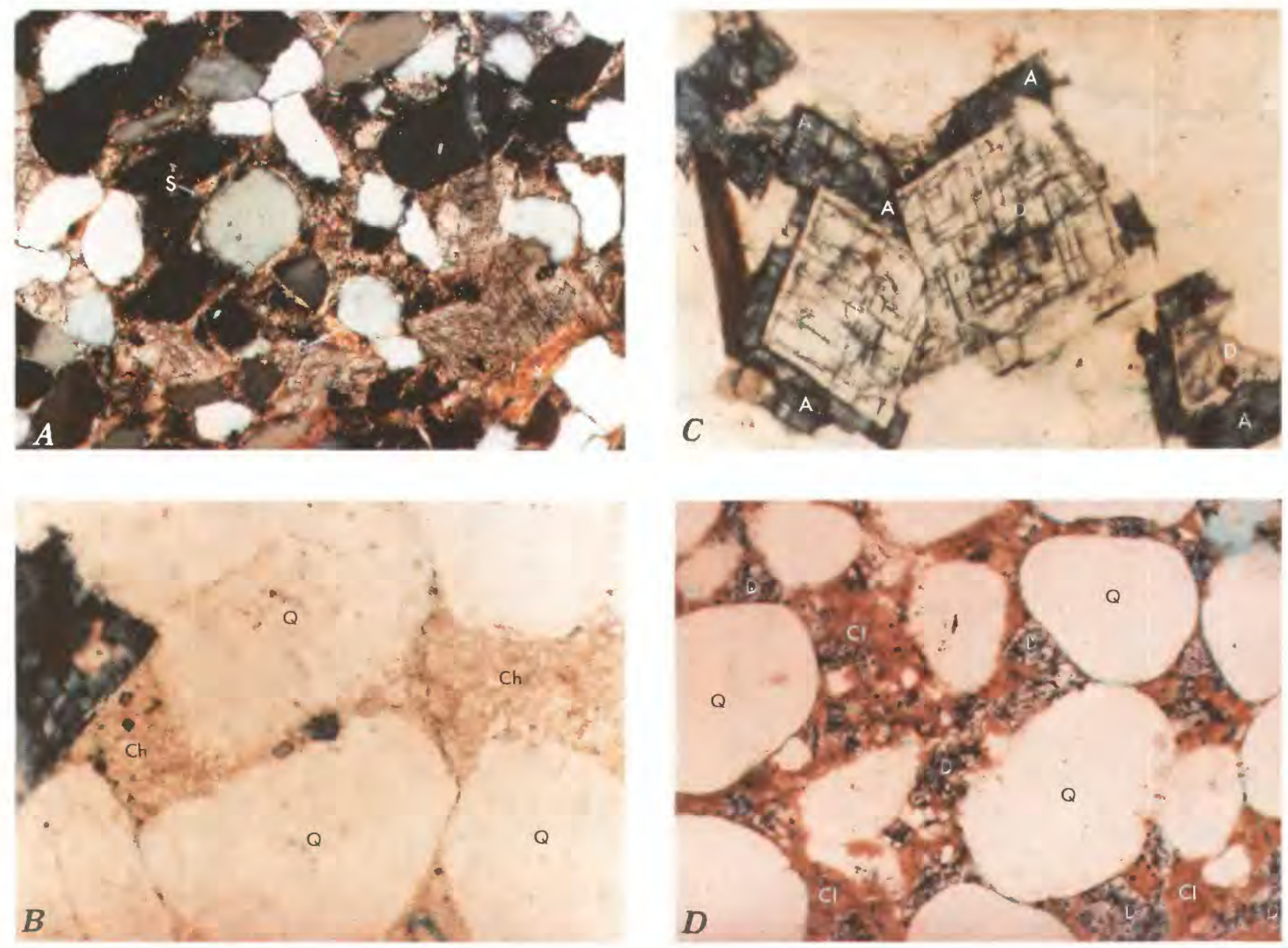

Figure 11. Thin section photomicrographs of sandstones of the Simpson Group from the Mazur well. Scale bars are 0.2 mm. A, Sericitic (S) clay cement. Tulip Creek Formation, 16,297 ft; crossed nicols. B, Pore-filling pseudomorphs of chlorite (Ch) after kaolinite. Q, quartz. Bromide Formation, 16,083 ft. C, Dolomite (D) rhombs and darker stained ankerite (A) overgrowths. Tulip Creek Formation, $16,290 \mathrm{ft}$. D, Dolomite (D) replacing clay $(\mathrm{Cl})$ in sandstone. Bromide Formation, $15,966 \mathrm{ft}$.

cement in a sandstone of the Bromide Formation at about $16,000 \mathrm{ft}$. The overall texture of the clay cement is a honeycomb or cornflake morphology that is typical of smectite. A high-magnification SEM image of the cement (fig. 13B) shows that the honeycomb- or cornflake-like surfaces have a finer intergrowth fabric of interwoven tabular fibers that is characteristic of illite. It is proposed here that illite is a pseudomorphic intergrowth after smectite. In addition, subsequent overgrowths of tabular illite fibers are superimposed on the edges of the honeycombs (figs. 13A and $B$ ). Similar morphology and texture observed in shale (fig. $13 C$ ) suggest some recrystallization of a smectite-rich precursor to the present illite composition.

Iron-rich chlorite is the dominant clay mineral in six sandstone samples and a minor component in most. Diagenetic iron-rich chlorite is present in two forms. More commonly, it is a pore-lining clay cement that was precipitated directly from pore fluids; it coats framework grains and is present as characteristic pseudohexagonal or ragged-edged, thin, clay plates forming an overall "house of cards" or rosette structure (fig. 10A). It also is a pseudomorphic replacement after pore-filling, vermicular kaolinite (figs. $11 B$ and $13 D$ ). The chemistry of iron chlorite pseudomorphs was confirmed by energy-dispersive $\mathrm{X}$-ray analysis.

Typically, kaolinite is precipitated from pore fluids during or immediately following carbonate dissolution (Lindquist, 1978; Loucks and others, 1979; Pollastro. 1989b; Surdam and others, 1989). Based on the spatial and textural relations observed in this study and the common paragenetic sequences reported elsewhere for sandstone, kaolinite was probably precipitated as a pore-filling clay at the same time an earlier pore-filling carbonate (calcite?) cement was being dissolved. Both processes occur in acidic pore waters. Surdam and others (1989) proposed that these reactions occur in the "zone of intense diagenesis" and in a burial temperature interval from 80 to $120^{\circ} \mathrm{C}$. The reactions are thought to be produced by increasing concentrations of organic acids that dissolve carbonate minerals and feldspar 


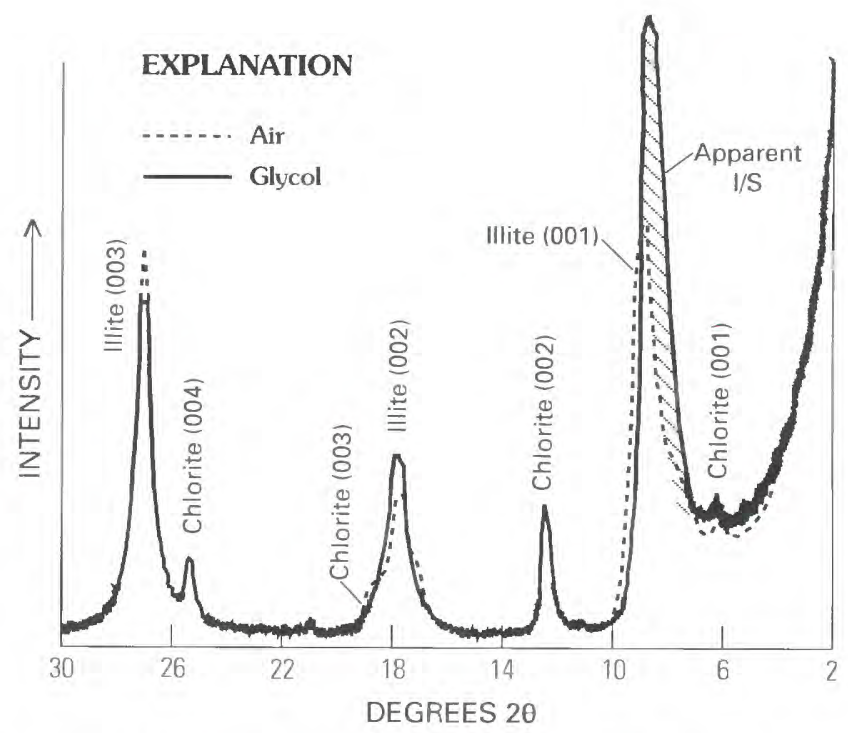

Figure 12. Typical X-ray powder diffraction profiles of oriented, $<2-\mu \mathrm{m}$ fraction of rocks of the Simpson Group from Mazur well showing discrete illite, chlorite, and apparent mixed-layer illite/smectite (I/S) basal (001) reflections. Apparent $\mathrm{I} / \mathrm{S}$ defined by diagonal pattern. $\mathrm{Cu} \mathrm{K}_{\alpha}$ radiation.

and precipitate kaolinite, chlorite, and other phases. Kaolinite in the Simpson samples probably was later replaced, or was converted to, iron-rich chlorite during maximum burial.

Using the models of Schmoker (1986) and Pollastro and Schmoker (1989), burial- and thermal-history reconstructions were made for the Mazur well. Burial-history reconstructions for the Anadarko basin suggest a minimum erosion estimate of about 2,600 ft (Schmoker, 1986). Assuming a constant geothermal gradient of $1.3{ }^{\circ} \mathrm{F} / 100 \mathrm{ft}$ $\left(2.37{ }^{\circ} \mathrm{C} / 100 \mathrm{~m}\right)$ and a mean annual surface temperature during maximum burial of $65{ }^{\circ} \mathrm{F}\left(17{ }^{\circ} \mathrm{C}\right)$, maximum estimated temperatures for the uppermost $(15,900 \mathrm{ft}, 4,850$ $\mathrm{m})$ and lowermost $(17,200 \mathrm{ft}, 5,240 \mathrm{~m})$ cored intervals in the Mazur well are 150 and $160^{\circ} \mathrm{C}$, respectively.

The clay minerals in the Simpson Group of the Mazur well can be used as geothermometers. Applying the model of Hoffman and Hower (1979), an assemblage of illite, ordered $I / S(R \geq 1)$, and chlorite and a distinct absence or disappearance of kaolinite and smectite indicate that burial temperatures were at least $150^{\circ} \mathrm{C}$.

\section{Formation of Dolomite and Ankerite Cements}

Cementation and replacement by dolomite, both ferroan and nonferroan, and ankerite was pervasive throughout the entire section of Simpson Group rocks in the Mazur core. These authigenic phases are present as isolated rhombs to extensive cements in both sandstones and carbonate rocks. The evolution of dolomitic cements is similar to the evolution of ferroan calcite cements; iron-rich dolomite or ankerite replaced or succeeded earlier iron-free or iron-poor dolomite. This order of genesis is best displayed by stained thin sections in which darker stained overgrowths of ankerite encase rhombs of earlier, clearer iron-free dolomite (fig. 11C).

There is a consistent relation where rhombs of dolomite or ankerite are proximally and texturally associated with clay and calcite. The dolomite and ankerite commonly replace detrital clay matrix (figs. $10 \mathrm{~B}$ and $11 D$ ). Boles (1978) proposed that the spatial associations between carbonate and clay in sandstones of the Wilcox Group (Eocene) of southwestern Texas suggest that ankerite formation was the direct product of calcite dissolution and smectite diagenesis at temperatures in excess of $125^{\circ} \mathrm{C}$. It is also suggested here that some late dolomite and ankerite cements were formed during the conversion of smectite to illite. Several investigators have suggested that the release of calcium, magnesium. and iron from the smectite to illite reaction produces dolomite and other authigenic mineral phases in sedimentary rocks during deep burial diagenesis (Boles and Franks, 1979; McHargue and Price, 1982; Pollastro, 1985). The consistent spatial and textural relations of dolomite, clay, and calcite and the absence of smectite, as determined from XRD profiles, support the concept that clay-mineral diagenesis played a role in the formation of late dolomite and ankerite.

The formation of dolomite and ankerite from clay is illustrate $e_{\text {in }}$ figure $14 \mathrm{~A}$ based on spatial relationships shown in th nhotomicrograph of figure 14B. Calcium, iron, and magn -iuni are released during the conversion of smectite to inlite. As smectite is converted to illite, smectite is dissolved and illite is precipitated (Nadeau, 1985; Pollastro, 1985). Calcium, magnesium, and iron probably nucleate dolomite and ankerite within the clay matrix of sandstones, and dolomite and ankerite grow, in part, at the expense of the clay. Similar to the interpretation of Boles (1978), much of the calcium for dolomite and ankerite formation in sandstones of the Simpson Group is probably derived from the dissolution of local calcite cement. This reaction mechanism is thought to have formed some of the dolomite and ankerite; however, it cannot explain the extensive cementation by ankerite.

\section{SUMMARY}

Rocks of the Simpson Group from the Mazur well consist mainly of quartz sandstone, clay-rich shale, and mixed carbonate rocks. Although whole-rock mineral compositions of the Simpson Group from the Mazur well are somewhat variable, clay minerals are mainly illite and chlorite. The clay-mineral assemblage in rocks at these depths is mostly the result of diagenesis wherein burial temperatures exceeded $150{ }^{\circ} \mathrm{C}$. Clay diagenetic reactions may also have contributed directly to the formation of late 

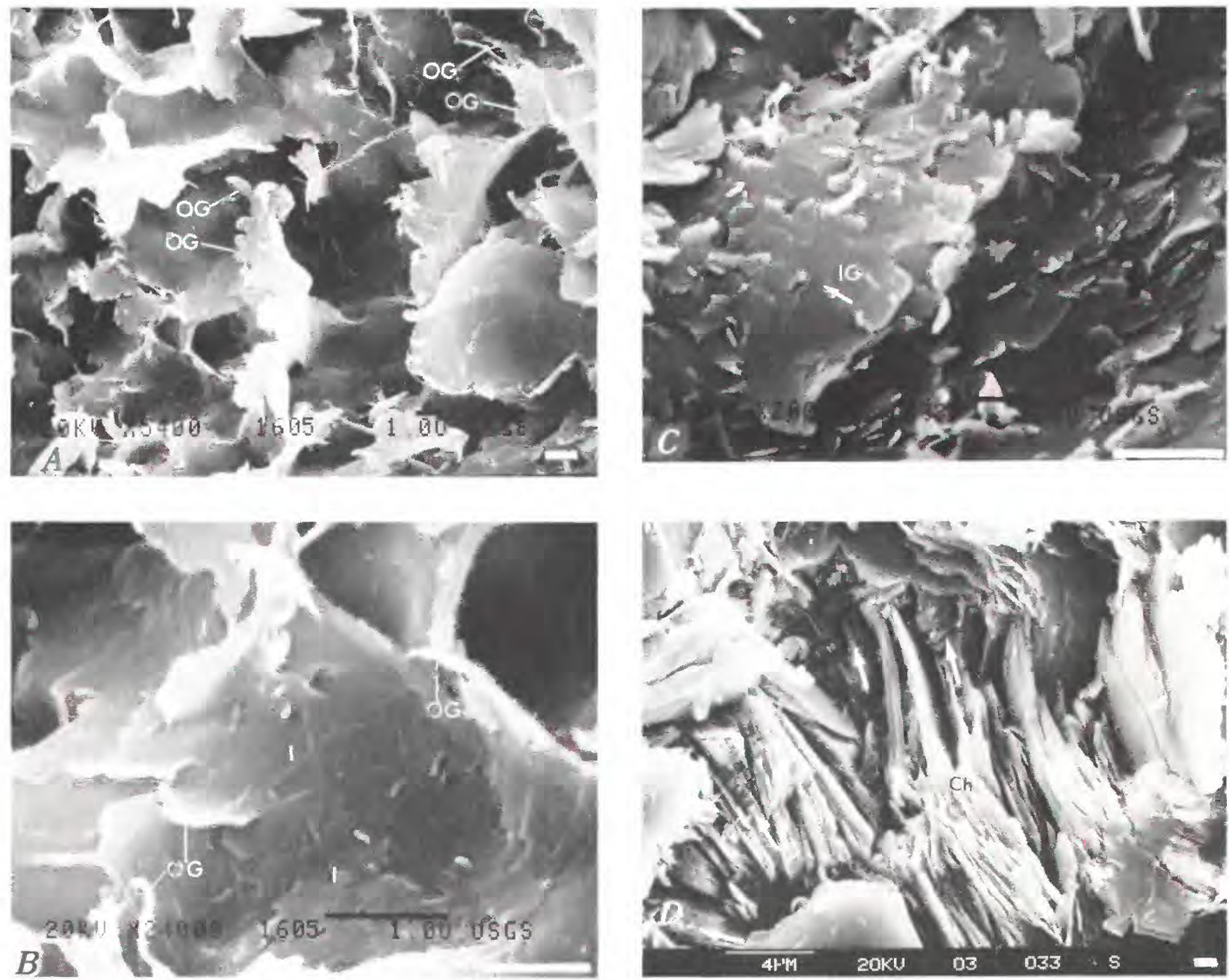

Figure 13. Scanning electron micrographs of rocks of the Simpson Group from the Mazur well. Scale bars are 1.0 $\mu$ m. A, Illitic cement with cornflake habit and illite overgrowths (OG) in sandstone. B, Higher magnification of cement in $A$ showing intergrowths (I) and overgrowths (OG) of tabular fibers of illite. C, Shale fabric showing platelets (I) and intergrowths (IG) of illite. $D$, Stacked clay plates of pseudomorphic pore-filling chlorite (Ch) after kaolinite. Note striated dissolution features (arrows) characteristic of vermicular kaolinite.

dolomite and ankerite cements in sandstone. Most sandstones are quartzarenites that commonly contain appreciable cement. Petrologic observations show that original textures and whole-rock mineral compositions of sandstones were significantly modified by replacement and cementation by carbonate minerals. Shales are clay rich and quartz poor; either they formed mainly from volcanic debris, or some silica was removed during progressive burial; some silica expelled from deep burial diagenesis of shales may have also been transported updip for early quartz cementation in sandstones. Secondary porosity, as much as 11 percent, is best developed in sandstones from the Tulip Creek and Oil Creek Formations and resulted from the dissolution of earlier carbonate cements.

\section{REFERENCES CITED}

Alder, J.J., 1971, Anadarko basin and central Oklahoma area, in Future petroleum provinces of the U.S.-Their geology and potential: American Association of Petroleum Geologists Memoir 15, p. 1061-1070.

Boles, J.R., 1978, Active ankerite cementation in the subsurface Eocene of southwest Texas: Contributions to Mineralogy and Petrology, v. 68, p. 13-22.

Boles, J.R., and Franks, S.G., 1979, Clay diagenesis in Wilcox sandstones of southwest Texas-Implications of smectite diagenesis on sandstone cementation: Journal of Sedimentary Petrology, v. 49, p. 55-70.

Burtner, R.L., and Warner, M.A., 1986, Relationship between illite/smectite diagenesis and hydrocarbon generation in Lower Cretaceous Mowry and Skull Creek Shales of the 

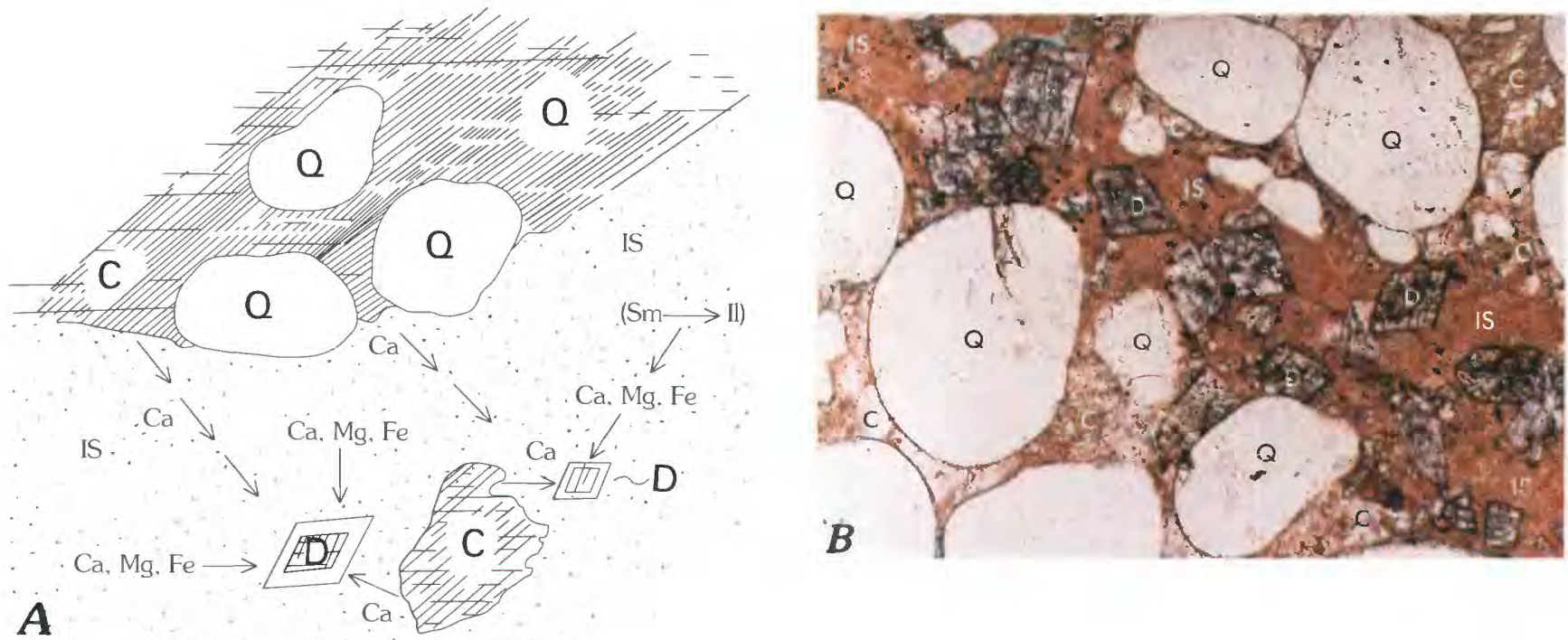

Figure 14. Formation of authigenic dolomite and ankerite in deeply buried rocks of the Simpson Group from the Mazur well. $A$, Diagrammatic interpretation of textures in thin section photomicrograph in $B$ showing the formation and evolution of dolomite and ankerite (D) from clay (IS) and calcite (C) cement. Elements exchanged in the reaction when smectite (Sm) is converted to illite (II) include calcium (Ca), magnesium (Mg), and iron (Fe) in deeply buried sandstones and carbonate rocks. Q, quartz. Scale bar in $B$ is $0.2 \mathrm{~mm}$.

northern Rocky Mountain area: Clays and Clay Minerals, v. 34 , p. $390-402$.

Carson, B., and Arcaro, N.P., 1983, Control of clay-mineral stratigraphy by selective transport in Late PleistoceneHolocene sediments of northern Cascadia basin-Juan de Fuca Abyssal Plain-Implications for studies of claymineral provenance: Journal of Sedimentary Petrology, v. 53, p. $395-406$.

Decker, C.E., and Merritt, C.A., 1931, The stratigraphy and physical character of the Simpson Group: Oklahoma Geological Survey Bulletin 55, 112 p.

Dickson, J.A.D., 1966, Carbonate identification and genesis as revealed by staining: Journal of Sedimentary Petrology, v. 36, p. 491-505.

Drever, J., 1973, The preparation of oriented clay mineral specimens for X-ray diffraction analysis by a filter membrane peel technique: American Mineralogist, v. 58, p. 395406.

Gautier, D.L., ed., 1986, Roles of organic matter in sediment diagenesis: Society of Economic Paleontologists and Mineralogists Special Publication 38, 203 p.

Hoffman, J., 1976, Regional metamorphism and K-Ar dating of clay minerals in Cretaceous sediments of the disturbed belt of Montana: Cleveland, Ohio, Case Western Reserve University, Ph.D. thesis, $266 \mathrm{p}$.

Hoffman, J., and Hower, J.. 1979, Clay mineral assemblages as low-grade metamorphic geothermometers-Application to the thrust faulted disturbed belt of Montana, U.S.A., in Scholle, P.A., and Schluger, P.K., eds., Aspects of diagenesis: Society of Economic Paleontologists and Mineralogists Special Publication 26, p. 55-79.

Hosterman, J.W., and Whitlkow, S.I., 1983, Clay mineralogy of Devonian shales in the Appalachian basin: U.S. Geological Survey Professional Paper 1298, 31 p.
Houseknecht, D.W., 1988, Intergranular pressure solution in four quartzose sandstones: Journal of Sedimentary Petrology, v. 58, p. $228-246$.

Hower, J., 1981, Shale diagenesis, in Longstaffe, F.J., ed., Clays and the resource geologist: Mineralogical Association of Canada Short Course Handbook 7, v. 6, p. 60-80.

Hower, J., Eslinger, E., Hower, M., and Perry, E., 1976, The mechanism of burial diagenetic reactions in argillaceous scdiments; 1, Mineralogical and chemical evidence: Geological Society of America Bulletin, v. 87, p. 725-737.

Johnson, K.S., Burchfield, M.R., and Harrison, W.E., 1984, Guidebook for Arbuckle Mountain field trip, southern Oklahoma: Oklahoma Geological Survey Special Publication 84-1, 21 p.

Lewis, R.D, 1982, Depositional environments and paleoecology of the Oil Creek Formation (Middle Ordovician), Arbuckle Mountains and Criner Hills, Oklahoma: University of Texas at Austin, Ph.D. thesis, $351 \mathrm{p}$.

Lindquist, S.J., 1978, How mineral content affects reservoir quality of sands: World Oil, April 1978, p. 99-102.

Longman, M.W., 1976, Depositional history, paleoccology, and diagenesis of the Bromide Formation (Ordovician), Arbuckle Mountains, Oklahoma: University Texas at Austin, Ph.D. thesis, 327 p.

Loucks, R.G., Dodge, M. M., and Galloway, W. E., 1979, Contract report EG-77-5-05-5554: University of Texas Bureau of Economic Geology, $97 \mathrm{p}$.

MacGowan, D.B., and Surdam, R.C., 1988, Difunctional organic acid anions in oilfield waters: Organic Geochemistry, v. 12, p. 245-259.

McBride, E.F., 1987, Diagenesis of the Maxon Sandstone (Early Cretaceous), Marathon Region, Texas-A diagenetic quartzarenite: Journal of Sedimentary Petrology, v. 31, p. 98-107. 
McDonald, D.A., and Surdam, R.C., 1984, Clastic diagenesis: American Association Petroleum Geologists Memoir 37, $434 \mathrm{p}$.

McHargue, T.R., and Price, R.C., 1982, Dolomite from clay in argillaceous or shale-associated marine carbonates: Journal of Sedimentary Petrology, v. 51, p. 553-562.

Nadeau, P.H., 1985, The physical dimensions of fundamental clay particles: Clay Minerals, v. 20, p. 499-514.

Nadeau, P.H., Wilson, M.J., McHardy, W.J., and Tait, J.M., 1984a, Interparticle diffraction-A new concept for interstratified clays: Clay Minerals, v. 19, 757-769.

1984b, Interstratified XRD characteristics of physical mixtures of elementary clay particles: Clay Minerals, v. 19, p. $67-76$.

1985, The nature of some illitic clays from bentonites and sandstones-Implications for the conversion of smectite to illite during diagenesis: Mineralogical Magazine, v. 49, p. 393-400.

Naeser, N.D., and McColloh, T.H., eds., 1989, Thermal history of sedimentary basins: New York, Springer-Verlag, 320 p.

Pettijohn, F.J., 1975, Sedimentary rocks (3rd ed.): New York, Harper and Row, 628 p.

Pettijohn, F.J., Potter, P.E., and Siever, R., 1973, Sand and sandstone: New York, Springer-Verlag, 618 p.

Pitman J.K., and Burruss. R.C., 1988, Diagenesis of hydrocarbonbearing rocks in the Ordovician Simpson Group, southeast Anadarko basin, in Johnson, K.E., ed., Anadarko Basin Symposium, 1988: Oklahoma Geological Survey Circular 90 , p. 134-142.

Pollastro, R.M., 1977, A reconnaissance analysis of the clay mineralogy and major element geochemistry in the Silurian and Devonian carbonates of western New York-A vertical profile: State University of New York at Buffalo, M.A. thesis, $119 \mathrm{p}$.

1981, Authigenic kaolinite and associated pyrite in chalk of the Cretaceous Niobrara Formation. eastern Colorado: Journal of Sedimentary Petrology, v. 51, p. 553-562.

1982, A recommended procedure for the preparation of oriented clay-mineral specimens for X-ray diffraction analysis-Modifications to Drever's filter-membrane-peel technique: U.S. Geological Survey Open-File Report 82-71, $10 \mathrm{p}$.

1983, The formation of illite at the expense of illite/ smectite: Mineralogical and morphological support for a hypothesis [abs.]: Clay Minerals Society, 20th Annual Meeting, 32nd Annual Clay Minerals Conference, Buffalo, N.Y., Program and Abstracts. p. 82.

1985, Mineralogical and morphological evidence for the formation of illite at the expense of illite/smectite: Clays and Clay Minerals, v. 33, p. 265-274.

1989a, Mineralogic and textural relations in deeply buried rocks of the Simpson Group (Middle Ordovician)-Implications in diagenesis and petroleum geology, in Johnson, K.S., ed., Anadarko Basin Symposium, 1988: Oklahoma Geological Survey Circular 90, p. 194-208.

1989b, Mineral composition, petrography, and diagenetic modification of lower Tertiary and Upper Cretaceous sandstones and shales, northern Green River basin, Wyoming, in Law, B.E., and Spencer, C.W., eds., Geology of tight gas reservoirs in the Pinedale anticline area, Wyoming, and at the Multiwell Experiment site, Colorado: U.S. Geological Survey Bulletin 1886, p. D1-D40.

Pollastro, R.M., and Barker, C.E., 1986, Application of claymineral, vitrinite reflectance, and fluid inclusion studies to the thermal and burial history of the Pindale anticline, Green River basin, Wyoming, in Gautier, D.L., ed., Roles of organic matter in sediment diagenesis: Society of Economic Paleontologists and Mineralogists Special Publication 38, p. 73-83.

Pollastro, R.M., and Martinez, C.J., 1985, Whole-rock, insoluble residue, and clay mineralogies of marl, chalk, and bentonite, Smoky Hill Shale Member, Niobrara Formation near Pueblo, Colorado-Depositional and diagenetic implications, in Pratt, L.M., Kauffman, E.G., and Zelt. F.B., eds., Fine-grained deposits and biofacies of the Cretaceous Western Interior seaway-Evidence of cyclic sedimentary processes: Society of Economic Paleontologists and Mineralogists Field Trip Guidebook, p. 215-222.

Pollastro, R.M., and Pillmore, C.L, 1987, Mineralogy and petrology of the Cretaceous-Tertiary boundary clay bed and adjacent clay-rich rocks, Raton basin, New Mexico and Colorado: Journal of Sedimentary Petrology, v. 57, p. 456466.

Pollastro, R.M., and Schmoker, J.W., 1989, Relationship of clay diagenesis to temperature, age, and hydrocarbon generation-An example from the Anadarko basin, Oklahoma, in Johnson, K.S., ed., Anadarko Basin Symposium, 1988: Oklahoma Geological Survey Circular 90, p. 257261.

Pollastro, R.M., and Scholle, P.A., 1986, Diagenetic relationships in a hydrocarbon-productive chalk-The Cretaceous Niobrara Formation, in Mumpton, F.A., ed., Studies in diagenesis: U.S. Geological Survey Bulletin 1578, p. 219-236.

Rascoe, B., Jr., and Adler, F.J., 1983, Permo-Carboniferous hydrocarbon accumulations, Mid-Continent, U.S.A.: American Association of Petroleum Geologists Bulletin, v. 67, p. 979-1001.

Reynolds, R.C., Jr., 1980, Interstratified clay minerals, in Brindley, G.W., and Brown. G., eds., Crystal structure of clay minerals and their X-ray identification: Mineralogical Society, London, p. 247-303.

Reynolds, R.C., Jr., and Hower, J., 1970, The nature of interlayering in mixed-layer illite-montmorillonite: Clays and Clay Minerals, v. 18, p. 25-36.

Samson, S.D., Patchett, P.J., Roddick, J.C., and Parrish, R.R., 1989, Origin and tectonic setting of Ordovician bentonites in North America-Isotopic and age constraints: Geological Society of America Bulletin, v. 101, p. 1175-1181.

Schmoker, J.W., 1986, Oil generation in the Anadarko basin, Oklahoma and Texas - Modeling using Lopatin's method: Oklahoma Geological Survey Special Publication 86-3, $40 \mathrm{p}$.

Scholle, P.A., and Schluger, P.R., eds., 1979, Aspects of diagenesis: Society of Economic Paleontologists and Mineralogists Special Publication 26, 443 p.

Schoonmaker, J., Mackenzie, F.T., and Speed, R.C., 1986, Tectonic implications of illite/smectite diagenesis, Barbados accretionary prism: Clays and Clay Minerals, v. 34, p. $465-472$. 
Schramm, M.W., Jr., 1964, Paleogeologic and quantitative lithofacies analysis, Simpson Group, Oklahoma: American Association of Petroleum Geologists Bulletin, v. 48, p. 1164-1195.

Schultz, L.G., 1964, Quantitative interpretation of mineralogical composition from X-ray and chemical data for the Pierre Shale: U.S. Geological Survey Professional Paper 391-C, $31 \mathrm{p}$.

1978, Sample packer for randomly oriented powders in $\mathrm{X}$-ray diffraction analysis: Journal of Sedimentary Petrology, v. 48, p. 627-629.

Schultz, L.G., Tourtelot, H.A., Gill, J.R., and Boerngen, J.G., 1980, Composition and properties of the Pierre Shale and equivalent rocks, Northern Great Plains Region: U.S. Geological Survey Professional Paper 1064-B, 114 p.

Scotchman, I.C., 1987, Clay diagenesis in the Kimmeridge Clay Formation, onshore $\mathrm{UK}$, and its relation to organic maturation: Mineralogical Magazine, v. 51, p. 535-551.
Surdam, R.C., Crossey, L.J., Hagen, E.S., and Heasler, H.P., 1989, Organic-inorganic interactions and sandstone diagenesis: American Association of Petroleum Geologists Bulletin, v. 73 , p. 1-23.

Taylor, J.M., 1950, Pore-space reduction in sandstones: American Association of Petroleum Geologists Bulletin, v. 34, p. 701-716.

Weaver, C.E., 1979, Geothermal alteration of clay minerals and shales: Office of Nuclear Waste Isolation Technical Report 21, $176 \mathrm{p}$.

1989, Clays, muds, and shales, Developments in sedimentology 44: New York, Elsevier, 820 p.

Weber, S.J., 1987, Petrography and diagenesis of the McLish Formation, Simpson Group (Middle Ordovician), southeastern Anadarko basin, Oklahoma: Norman, Oklahoma State University, M.S. thesis, 98 p. 



\section{SELECTED SERIES OF U.S. GEOLOGICAL SURVEY PUBLICATIONS}

\section{Periodicals}

Earthquakes \& Volcanoes (issued bimonthly).

Preliminary Determination of Epicenters (issued monthly).

\section{Technical Books and Reports}

Professional Papers are mainly comprehensive scientific reports of wide and lasting interest and importance to professional scientists and engineers. Included are reports on the results of resource studies and of topographic, hydrologic, and geologic investigations. They also include collections of related papers addressing different aspects of a single scientific topic.

Bulletins contain significant data and interpretations that are of lasting scientific interest but are generally more limited in scope or geographic coverage than Professional Papers. They include the results of resource studies and of geologic and topographic investigations; as well as collections of short papers related to a specific topic.

Water-Supply Papers are comprehensive reports that present significant interpretive results of hydrologic investigations of wide interest to professional geologists, hydrologists, and engineers. The series covers investigations in all phases of hydrology, including hydrogeology, availability of water, quality of water, and use of water.

Circulars present administrative information or important scientific information of wide popular interest in a format designed for distribution at no cost to the public. Information is usually of short-term interest.

Water-Resources Investigations Reports are papers of an interpretive nature made available to the public outside the formal USGS publications series. Copies are reproduced on request unlike formal USGS publications, and they are also available for public inspection at depositories indicated in USGS catalogs.

Open-File Reports include unpublished manuscript reports, maps, and other material that are made available for public consultation at depositories. They are a nonpermanent form of publication that may be cited in other publications as sources of information.

\section{Maps}

Geologic Quadrangle Maps are multicolor geologic maps on topographic bases in 7 1/2-or 15-minute quadrangle formats (scales mainly $1: 24,000$ or $1: 62,500$ ) showing bedrock, surficial, or engineering geology. Maps generally include brief texts; some maps include structure and columnar sections only.

Geophysical Investigations Maps are on topographic or planimetric bases at various scales; they show results of surveys using geophysical techniques, such as gravity, magnetic, seismic, or radioactivity, which reflect subsurface structures that are of economic or geologic significance. Many maps include correlations with the geology.

Miscellaneous Investigations Series Maps are on planimetric or topographic bases of regular and irregular areas at various scales; they present a wide variety of format and subject matter. The series also includes 7 1/2-minute quadrangle photogeologic maps on planimetric bases which show geology as interpreted from aerial photographs. Series also includes maps of Mars and the Moon.
Coal Investigations Maps are geologic maps on topographic or planimetric bases at various scales showing bedrock or surficial geology, stratigraphy, and structural relations in certain coal-resource areas.

Oil and Gas Investigations Charts show stratigraphic information for certain oil and gas fields and other areas having petroleum potential.

Miscellaneous Field Studies Maps are multicolor or black-andwhite maps on topographic or planimetric bases on quadrangle or irregular areas at various scales. Pre-1971 maps show bedrock geology in relation to specific mining or mineral-deposit problems; post-1971 maps are primarily black-and-white maps on various subjects such as environmental studies or wildemess mineral investigations.

Hydrologic Investigations Atlases are multicolored or black-andwhite maps on topographic or planimetric bases presenting a wide range of geohydrologic data of both regular and irregular areas; principal scale is $1: 24,000$ and regional studies are at $1: 250,000$ scale or smaller.

\section{Catalogs}

Permanent catalogs, as well as some others, giving comprehensive listings of U.S. Geological Survey publications are available under the conditions indicated below from the U.S. Geological Survey, Books and Open-File Reports Section, Federal Center, Box 25425, Denver, CO 80225. (See latest Price and Availability List.)

"Publications of the Geological Survey, 1879-1961" may be purchased by mail and over the counter in paperback book form and as a set of microfiche.

"Publications of the Geological Survey, 1962-1970" may be purchased by mail and over the counter in paperback book form and as a set of microfiche.

"Publications of the U.S. Geological Survey, 1971- 1981" may be purchased by mail and over the counter in paperback book form (two volumes, publications listing and index) and as a set of microfiche.

Supplements for 1982, 1983, 1984, 1985, 1986, and for subsequent years since the last permanent catalog may be purchased by mail and over the counter in paperback book form.

State catalogs, "List of U.S. Geological Survey Geologic and Water-Supply Reports and Maps For (State)," may be purchased by mail and over the counter in paperback booklet form only

"Price and Availability List of U.S. Geological Survey Publicathons," issued annually, is available free of charge in paperback booklet form only.

Selected copies of a monthly catalog "New Publications of the U.S. Geological Survey" available free of charge by mail or may be obtained over the counter in paperback booklet form only. Those wishing a free subscription to the monthly catalog "New Publications of the U.S. Geological Survey" should write to the U.S. Geological Survey, 582 National Center, Reston, VA 22092.

Note.--Prices of Government publications listed in older catalogs, announcements, and publications may be incorrect. Therefore, the prices charged may differ from the prices in catalogs, announcements, and publications. 


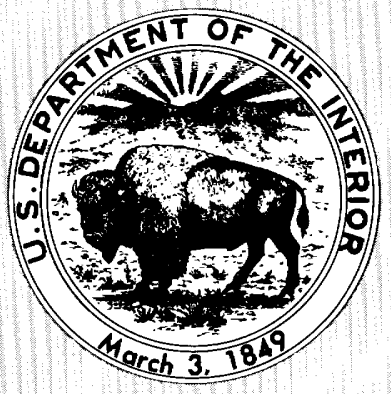

